Tine Germ

\title{
Simbolika orla in sonca v emblemih Spominske knjige ljubljanske plemiške družbe sv. Dizma
}

\section{Uvod}

Spominska knjiga ljubljanske plemiške družbe sv. Dizma ali krajše Dizmova kronika, hranjena v Arhivu Republike Slovenije (AS 1073, I/1), je bila v zadnjih dveh desetletjih deležna pozornosti predvsem zaradi edinstvenih, izredno zanimivih emblemov. Ljubljanski rokopis, ki so ga zasnovali in soustvarjali člani leta 1688 ustanovljene plemiške družbe sv. Dizma, ni klasična emblemska knjiga, temveč izvirna oblika akademske spominske knjige, v kateri so predstavljeni emblemi, imena njenih članov, njihovi grbi in podatki o vpisu v družbo. Prve miniature so nastale leta 1689, zadnji člani pa so bili vpisani leta $1801 .{ }^{1}$ Kakovost iluminacij in njihovo ikonografsko bogastvo sta izjemna, tako da Dizmova kronika upravičeno velja za najdragocenejši baročni iluminirani rokopis, kar se jih je ohranilo na Slovenskem. Med emblemi so z ikonografskega vidika še posebej zanimivi tisti, ki vključujejo živali kot nosilce alegoričnega sporočila. Število tovrstnih emblemov in pester nabor živali jasno odražata zanimanje naročnikov za živalsko simboliko kot tudi široke možnosti izražanja emblemskega sporočila, ki jih ponuja. Hkrati lahko v tem prepoznamo odmev sočasnih evropskih tokov na področju emblematike, v kateri imajo živali od vsega začetka pomembno vlogo. Priljubljenost živalskih motivov v Dizmovi kroniki je pogojena tudi z dejstvom, da gre za spominsko knjigo, v kateri so natančno naslikani grbi vseh članov. Grbi v večini primerov vključujejo heraldične živali, kar je vplivalo tudi na izbiro živalskih protagonistov v emblemih naročnikov.

Prominentna vloga živali v evropski heraldiki je pomembno zaznamovala že samo genezo renesančnega emblema. (Spomnimo, da Alciati, avtor prve emblemske knjige, uvodni emblem v znameniti Emblematum liber zasnuje na podobi grbovnega ščita milanskih vojvod in v njem razlaga pomen kače s človeško figuro v ustih. ${ }^{2}$ ) Vpliv heraldike na emblematiko ostaja stalnica v razvoju emblemskih knjig, neposredna povezanost pa je prav posebej očitna v primerkih, ki so posvečeni vladarjem, visokemu plemstvu,

1 Med novejšimi raziskavami Dizmove kronike in zlasti ikonografije emblemov glej Germ 2011 in 2017.

2 Alciati, 1531, A2r-A2v.

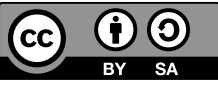

DOI:10.4312/ars.14.2.181-210 
cerkvenim dostojanstvenikom in drugim odličnikom, ${ }^{3}$ ter v posameznih emblemsko zasnovanih knjigah renesančnih akademij in spominskih knjigah plemiške mladine, ki je študirala na različnih evropskih univerzah (t. i. alba amicorum ali libri amicorum). Ob tem velja spomniti, da so poleg akademskih emblemskih knjig prav alba amicorum eden od pomembnih zgledov, ob katerih so se navdihovali člani Dizmove družbe. ${ }^{4}$

Vloga heraldičnih živali pri oblikovanju emblemov članov Akademije Zedinjenih ${ }^{5}$ se odraža tudi v njihovem izboru: najpogostejši je namreč orel, žival, ki si v evropski heraldiki skupaj $\mathrm{z}$ levom deli prvo mesto tako $\mathrm{z}$ vidika pogostosti pojavljanja kot $\mathrm{z}$ vidika odličnosti in bogastva simbolnih pomenov. Ko govorimo o priljubljenosti orla $\mathrm{v}$ emblemih imenitnih Kranjcev, združenih v družbi sv. Dizma, ne smemo pozabiti, da je orel heraldična žival Vojvodine Kranjske in da so ga zaradi tega včasih v embleme vključili tudi plemiči, ki kraljevske ptice niso imeli v svojem grbu. O pomenu kranjskega grbovnega orla v ljubljanski Spominski knjigi posebej nazorno priča vpisna stran grofa Janeza Henrika Watzenberga (fol. 63r). ${ }^{6}$ Ta namreč nima klasične emblemske strukture, ampak se napisni trak $\mathrm{z}$ devizo In magnis voluisse sat est ( $V$ velikih rečeh sama je volja dovolj) ovija kar okrog vratu mogočnega črnega orla, ki razširjenih peruti stoji na vrhu naročnikovega grba. Dva enako velika orla sta upodobljena tudi ob grbovnem ščitu, v katerem nastopa še dvoglavi cesarski orel habsburške monarhije. Orel nad ščitom se s svojo držo in veličastjem nedvoumno spogleduje s heraldično ptico dežele Kranjske, po drugi strani pa s tem, ko nosi napisni trak z geslom, aludira na naročnika. Takšno razlago potrjuje primerjava s študijsko skico, ki jo je za Watzenbergov emblem pripravil Janez Gregor Dolničar v svoji Konceptni knjigi (sl. št. 27). ${ }^{7}$ Na njej je orel upodobljen v kartuši, na prsih pa ima vrisano stilizirano srce, simbol plemiške družbe sv. Dizma. Andrej Trost (1643-1708), vodilni iluminator v zgodnjem obdobju nastajanja ljubljanske Spominske knjige in verjetni avtor miniature, se je odločil, da ne bo dosledno sledil predlaganemu Dolničarjevemu konceptu in je v končni obliki Watzenbergovega emblema naslikal orla brez stiliziranega srca na prsih. Posledično je simbolna vez z Dizmovo družbo manj očitna, identifikacija s kranjskim heraldičnim orlom pa še bolj izpostavljena in potrjuje

3 Med prvimi tovrstnimi knjigami glej: Giovanni Battista Pittoni, Imprese di diversi prencipi, duchi, signori, e d'altri personaggi et huomini letterati et illustri ..., Benetke 1562; Girolamo Ruscelli, Imprese illustri ..., Benetke (vol. I-III. 1572, Libro quarto 1583).

4 Alba amicorum imajo z Dizmovo kroniko vsaj dve bistveni skupni lastnosti: nastajali so kontinuirano, $\mathrm{v}$ daljšem obdobju kot odprti tip ilustrirane knjige ali vezanih rokopisnih listov z bolj ali manj sofisticiranimi iluminacijami, ob tem pa imajo njihovi vpisni listi neredko podobno strukturo kot strani v ljubljanski Spominski knjigi. Vizualno izpostavljena grb in emblem, dopolnjena z osebnimi podatki in datumom vpisa, se skupaj pojavljata znotraj istega vpisa ter oblikujeta zaokroženo likovno in vsebinsko celoto.

5 Plemiška družba sv. Dizma je uporabljala tudi latinski naziv Academia Unitorum, torej Akademija Zedinjenih, člani pa so se imenovali Academici Uniti.

6 Navajanje folijev v Dizmovi kroniki sledi foliaciji, ki jo je za faksimilno izdajo leta 2001 pripravila N. Golob.

7 Dolničar je kot prvi tajnik Dizmove družbe in njen idejni vodja izdelal tudi nekaj študijskih skic emblemov za člane družbe. Njegova Konceptna knjiga (Semeniška knjižnica, Ljubljana, sign. Rokopis 6) vsebuje 83 skic za emblemske sličice v ovalnih kartušah, eno kartušo, v kateri je samo osnutek srca, in kar nekaj praznih kartuš (Baraga, 2001, 235). 
vlogo heraldike v emblemih kranjskih akademikov. Hkrati gre za prvi primer aktivnega posega slikarja v samo ikonografsko zasnovo emblema, ki razkriva pomemben vidik geneze emblemov v Dizmovi kroniki, s katerim se bomo še srečali.

V Spominski knjigi se orel kot nosilec emblemskega sporočila največkrat pojavlja $\mathrm{v}$ povezavi s soncem. Motiv orla in sonca je zaradi uveljavljene ikonografske tradicije v emblematiki zelo priljubljen, vendar pogostost in raznolikost motiva v emblemih kranjskih akademikov vzbujata pozornost in kličeta po razlagi. V Dizmovi kroniki se namreč pojavi kar desetkrat in vsakič ima specifično pomensko noto. V ikonografskem katalogu, ki je nastal ob faksimilni izdaji Spominske knjige ljubljanske plemiške družbe sv. Dizma, Jože Kastelic (2001, 115-261) ne ponudi ikonografske razlage za omenjene embleme. Prav tako se z motivom ni ukvarjal nihče od starejših avtorjev, ki so pisali o knjigi ljubljanskih akademikov. Pričujoča raziskava je prvi poskus ikonološke analize izbranih emblemov $\mathrm{v}$ primerjalnem okviru evropske emblematike. Kasteličev katalog s predikonografskim opisom in prevodom besedilnih delov (akademsko ime člana, izbrano geslo ter dodatni napisi $)^{8}$ predstavlja dragoceno izhodišče za nadaljnje raziskave, ki, razumljivo, zahtevajo vpogled v ikonografijo orla v evropski kulturi od antike do baroka ter poznavanje emblematike 16. in 17. stoletja. Številni tvorci emblemskih knjig ob razlagi emblemov $\mathrm{v}$ potrditev svojih besed navajajo odlomke iz del klasičnih avtorjev, cerkvenih očetov, srednjeveških piscev in svojih sodobnikov, s čimer gradijo hermenevtični korpus, ki ima za raziskovalce neprecenljivo vrednost. Posebno mesto v tem pogledu pripada Filippu Picinelliju, ki v obsežni enciklopediji emblemov Mundus Symbolicus predstavi več kot sto emblemov, v katerih je orel glavni nosilec alegoričnega sporočila (I, 4, embl. 89-217). ${ }^{9}$ $Z$ vidika pričujoče študije je Picinellijeva zbirka emblemov toliko pomembnejša, ker je bila zelo popularna tudi med kranjskimi intelektualci in predstavlja enega od poglavitnih virov za embleme v Dizmovi kroniki (Germ, 2017, 151-152).

\section{Orel in sonce v emblemih članov Akademije Zedinjenih}

Pogostost motiva orla in sonca v emblematiki ne preseneča, saj v evropski kulturi kontinuirano živi vse od antike, v zgodnjem krščanstvu in srednjem veku pa doživlja intenziven razvoj zlasti na področju sakralne ikonografije. Zlivanje antičnih tem s krščanskimi daje izhodišče za večino motivov, ki jih najdemo v renesančni emblematiki. Hkrati se prav v tem okviru razvijejo tudi nove vsebine, ki jih v starejših obdobjih ne srečamo. V emblemih Dizmove kronike prevladuje tematski sklop, ki se navezuje

8 Prevod latinskih delov besedila je oskrbel K. Gantar. Avtor članka jih z redkimi izjemami navaja dobesedno. V primeru manjših odmikov od Gantarjevega prevoda je na to dosledno opozorjeno.

9 Picinellijeva knjiga je prvič izšla v italijanskem jeziku Mondo simbolico ... v Milanu leta 1653. Kmalu je bila prevedena v latinščino in večkrat ponatisnjena: Mundus symbolicus: in emblematum universitate formatus, explicatus ... justo volumine auctus et Latinum traductus a R. D. Augustino Erath, Köln 1681. Vsi navedki Picinellija se nanašajo na kölnsko izdajo iz leta 1681, zato je uporabljena skrajšana oblika z navedbo zvezka (rimske številke) ter številko knjige in emblema (arabske številke). 
na kristološko ikonografijo orla in sonca, z njim pa se povezujejo alegorične vsebine preroda duše, odrešenja in večnega življenja ter predstave o kontemplaciji, sledenju Kristusovemu nauku in duhu, ki se dviga v nebeške višave. Posebej so izpostavljeni štirje motivi, ki izvirajo iz antike, a so v krščanstvu dobili nove, precej bolj kompleksne vsebine: orel, ki nemoteno zre v sonce; orel, ki leti proti soncu; preizkušnja mladih orličev z gledanjem v sonce; orel, ki uči mladiče leteti. Ob tem je treba imeti pred očmi dejstvo, da se v emblematiki krščanski koncept spoznavajočega duha, ki se dviga v višave, povezuje s humanističnimi predstavami o odličnosti intelekta, ki ga vodi želja po znanju in spoznanju resnice. Intelektualna nota je v emblemih kranjskih akademikov večkrat jasno naglašena. Enako velja za zanimanje za antiko, zato elementi antične ikonografije, povezane s solarno simboliko orla in orlom kot Jupitrovo sveto ptico, ne presenečajo. Naštete vsebine in motivi se medsebojno dopolnjujejo, zaradi česar je v kompleksnejših emblemih potrebna previdnost pri razlagi alegoričnega sporočila.

Prvi v nizu emblemov z motivom orla in sonca pripada Janezu Jožefu pl. Wallenspergu (fol. 119r), s katerim začenjamo pregled tudi zato, ker je ikonografsko razmeroma preprost, čeprav je osnovna vsebina tudi tu premišljeno dopolnjena z manj očitnimi simbolnimi pomeni (slika 1).

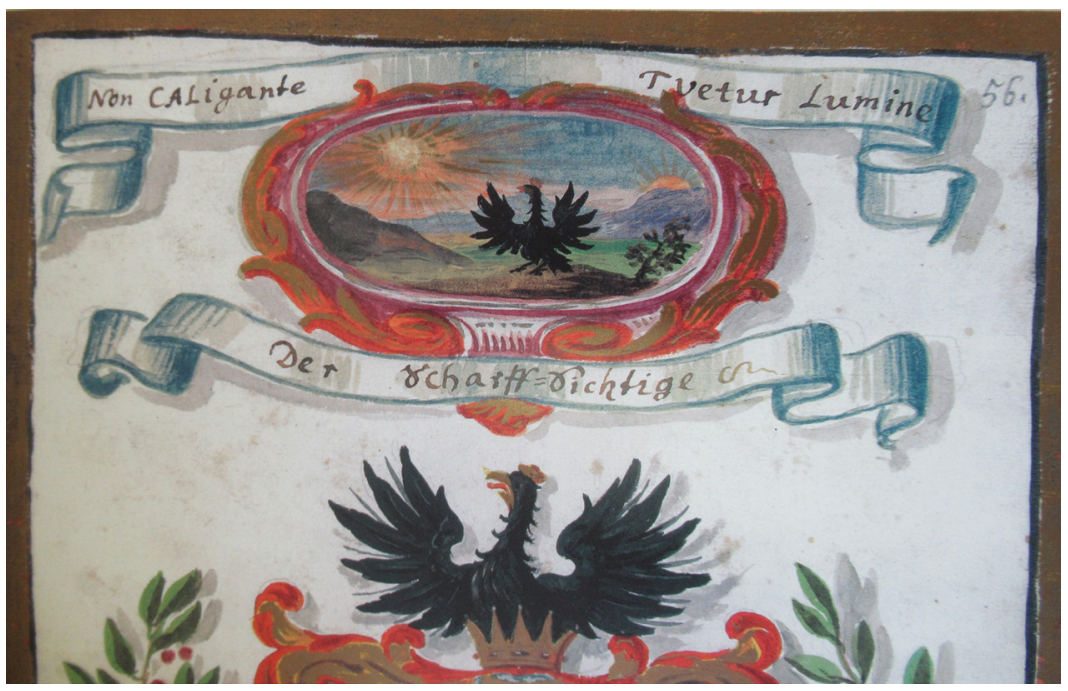

Slika 1: Andrej Trost, Emblem Janeza Jožefa pl. Wallensperga (detajl), 1700, Dizmova kronika, ARS, Ljubljana, AS 1073, I/1, fol. 119r. ${ }^{10}$

Emblemska sličica kaže mogočno kraljevsko ptico, postavljeno v prvi plan gričevnate pokrajine, obsijane s soncem, ki se dviga nad hribe na levi strani miniature. Orel stoji

10 Navedene letnice se nanašajo na leto vpisa v Dizmovo kroniko. 
na tleh, razpira peruti in gleda naravnost v jutranje sonce. Posebnost upodobitve je v tem, da lahko na nasprotni strani vidimo sončni zahod, kar je edini primer v iluminacijah Dizmove kronike, da se sonce v istem prizoru pojavi dvakrat. Nad kartušo je napisni trak z geslom "Non caligante tuetur lumine "(Zre v svetlobo, ne da bi ga zaslepila), ${ }^{11}$ pod njo pa krajši, s članskim imenom Der Scharfsichtige (Ostrovidni). Geslo je najverjetneje vzeto iz verzov francoskega pesnika Laurenta le Bruna, v katerih pravi, da orel gleda sonce, ne da bi ga njegova luč zaslepila. ${ }^{12}$

Motiv Wallenspergove emblemske sličice ima prastare korenine - že Egipčani (pa tudi Grki in Rimljani) so verjeli, da lahko orel zre naravnost v sonce, ne da bi trenil z očmi ali odvrnil pogled. ${ }^{13}$ To nenavadno sposobnost omenja že Aristotel v Zgodovini živali (IX, 34), in povzemajo ga številni antični avtorji, med katerimi je za prenos vsebine v srednji vek bistven Plinij Starejši s svojim Naravoslovjem (X, 3). Alegorične interpretacije se $\mathrm{v}$ antiki praviloma povezujejo z Zevsovim orlom, kraljem ptic, ki leta višje kot ostali ptiči in se lahko najbolj približa soncu. Izpostavljajo predvsem njegovo veličastje, moč, plemenitost in pravičnost. ${ }^{14} \mathrm{~V}$ krščanstvu dobi motiv orla in sonca nove vsebine: sonce je skladno $\mathrm{z}$ razlagami zgodnjekrščanskih piscev praviloma simbol Kristusa (Christus sol iustitiae), orel, ki se zazira vanj, pa predstavlja vernika ali krščansko dušo, ki se preraja v luči prave vere in je deležna odrešitve v Kristusu. ${ }^{15}$ Prerod in duhovna prenova sta osrednja tema zapisa v Fiziologu (I, 6), kjer je osnovna vsebina orla, ki gleda v sončevo svetlobo, obogatena $\mathrm{z}$ motivom leta proti soncu in pomladitvijo s potapljanjem v bistro vodo. ${ }^{16} \mathrm{Krščanski} \mathrm{avtorji} \mathrm{ob} \mathrm{motivu} \mathrm{orlove} \mathrm{pomladitve} \mathrm{nava-}$ jajo besede psalmista, ki pravi: »[...] kakor orlu se obnavlja tvoja mladost « (Ps 103, 5).

11 V katalogu (Kastelic, 2001, 152) je geslo prevedeno kot: „Gleda v svetlobi, ki ne zatemni.« Gantarjev prevod ni najbolj posrečen: ne ujema se z vsebino emblema niti z uveljavljeno ikonografijo sorodnih emblemov v knjigah zgodnjega novega veka.

12 "Explorat Phoebum et non caligante tuetur lumine ..." (Laurentius Le Brun, Virgilius Christianus, I. Liber Fastorum, sive Hexaemeron \& de opere sex dierum, Paris 1661, 433) Verzi so navedeni tudi v večkrat ponatisnjeni zbirki Giovannija Battista Ganduccija, Descriptiones poeticae ex probatioribus poetis excerptae ..., Benetke 1676, 114.

13 Prepričanje, da lahko orel nemoteno gleda v sonce, ni iz trte zvito: orlovo oko ima polprozorno membrano (membrana nicitans), ki po potrebi kot tanka veka prekrije zrklo, ga vlaži in varuje, hkrati pa ptici kljub temu omogoča, da vidi.

14 Že Homer piše, da je orel med vsemi pticami Zevsu najljubši (Iliada, XVIII, 245-252; XXIV, 315321). Tudi Pindar ga imenuje Zevsovo ptico in kralja vseh ptic (Pitijske ode I, 6; Istmijske ode VI, 50; Olimpijske ode XIII, 21), Horacij pa eksplicitno zapiše, da je Jupiter orlu podelil oblast nad vsemi pticami (Ode, IV, 4). Orel kot kralj ptic nastopa pri Ezopu, na primer v basni Stržek in orel ter Orel in govnač (Perry, 1965, basen št. 434 in št. 3). Motiv orla kot Zevsove oziroma Jupitrove svete ptice ter njegova povezanost $\mathrm{z}$ idejo vladarstva dosežeta vrhunec v Rimu, kjer orel postane cesarski simbol.

$15 \mathrm{~V}$ posameznih interpretacijah motiva gledanja v sonce oziroma letenja proti soncu je lahko orel simbol Kristusa, sonce pa simbol Boga Očeta. Tako v spisu Psevdo Ambroža beremo: "Aquilam in hoc loco Christum Dominum nostrum debemus accipere, qui post venerandam resurrectionem ... velut aquila revolavit ad patrem ... «(Sermo 46. De Salomone, 5, PL 17, 718)

16 Navedeno po: Zucker, 2005, 78-82. Vsi sklici in navedbe iz Fiziologa so vzeti iz kritične izdaje grškega teksta (rokopis Fiziologa, ki ga hrani Pierpont Morgan Library, Ms 397) s francoskim prevodom Arnauda Zuckerja (Zucker, Paris 2005). Navajanje sledi uveljavljeni tradiciji: najprej navedba skupine, ki ji rokopis pripada, in nato navedba poglavja. Zaradi preglednosti je v opombi dodana stran pariške izdaje. 
Orel je z vstajenjsko simboliko povezan tudi v besedilih zgodnjekrščanskih piscev, na primer Psevdo Ambroža, ki ga v že omenjeni pridigi (Sermo 46. De Salomone) izrecno poveže s Kristusom. Sv. Avguštin v razlagi psalmov orla razume tudi kot prispodobo vstajenja vseh verujočih (Enarrationes in Psalmos, 102, 9, PL 37, 1323). Podoba orlovega zrenja v sonce je priljubljena tudi v srednjeveških alegoričnih interpretacijah - tako $\mathrm{v}$ bestiarijih kot v enciklopedičnih zapisih, eksegetskih besedilih in pridigah.

Motiv v zgodnjem novem veku ohranja svojo aktualnost - najdemo ga tudi v naravoslovnih zapisih. Večkrat ga omenjata oba največja renesančna zoologa Conrad Gessner (1516-1565) v Historiae animalium in Ulisse Aldrovandi (1522-1605) v knjigah o pticah Ornithologiae, hoc est de avibus historiae. ${ }^{17} \mathrm{~V}$ emblematiki je orel, ki gleda v sonce oziroma leti proti njemu, zelo pogost in Picinelli v knjigi Mundus Symbolicus predstavi kar osemindvajset emblemov, ki vključujejo ta motiv. ${ }^{18}$ Poleg že omenjenih vsebin, povezanih z vstajenjem, razlage največkrat govorijo o odprtosti duha, ki sprejema čisto luč Kristusovega nauka, kontemplaciji in predanosti veri. Pogosto je poudarjena povezava z Janezom Evangelistom, ki temelji na eksegetski ikonografiji: orel, ki se $\mathrm{z}$ lahkoto dvigne $\mathrm{v}$ nebesne višave in zre naravnost $\mathrm{v}$ sonce, je simbol vznesenega duha, ki veje iz besed najmlajšega med evangelisti.

Wallenspergovo akademsko ime Ostrovidni in izbrano geslo Zre v svetlobo, ne da bi ga zaslepila kažeta, da moramo emblemsko sličico razbirati v povezavi z idejo ostrovidnega zretja svetlobe v smislu prodornosti duha in kontemplacije (kar seveda ne izključuje s tem povezane ikonografije preroda). Moč duha, da vztrajno sledi soncu, je $\mathrm{v}$ sličici poudarjena $\mathrm{z}$ na videz nenavadnim pojavom: $\mathrm{v}$ istem prizoru sta hkrati vzhajajoče in zahajajoče sonce. Avtor emblema na ta način vnese dimenzijo časa: poudariti želi, da lahko orel nemoteno gleda v sonce od jutra do večera. S tem bralca dodatno opozarja, da je treba prizor razumeti v alegoričnem duhu. Glede na premišljene besedne igre in aluzije, ki jih neredko razkrivajo emblemi članov Dizmove družbe, lahko tudi v primeru Janeza Wallensperga s precejšnjo gotovostjo sklepamo, da je v emblemu skrit še namig na njegovo krstno ime: orel, ki gleda v sonce, je tudi v emblematiki povezan $\mathrm{z}$ evangelistom Janezom. Simbolična identifikacija $\mathrm{z}$ naročnikom je dodatno naglašena $\mathrm{z}$ dejstvom, da je črn orel heraldična ptica družine Wallensperg. Upodobitev orla v emblemu je povsem enaka kot v grbu, celo krona heraldičnega orla se kot miniaturna kronica ponovi na glavi kralja ptic $\mathrm{v}$ emblemski sličici.

17 Gessner, Historiae animalium (Lib. III, De avium natura, Zürich 1555, pogl. De aquila, 162-189), Aldrovandi, Ornithologiae, hoc est de avibus historiae Libri XII (Lib. I -II, Bologna 1599, 17-234). Zlasti Aldrovandijeva prva knjiga De aquilis in genere (1599, 17-107) ob navajanju naravoslovnih dejstev vsebuje pravo zakladnico ikonografskih vsebin, razdeljenih na poglavja: Historica, Auguria, Mystica, Hieroglyphica, Fabulae, ter posebno poglavje posvečeno emblemom: Emblemata (str. 72-75). Aldrovandi obširno piše tudi o orlu v heraldiki in likovni umetnosti.

18 Motiv orla in sonca vsebujejo emblemi 98-108, 120, 122, 123, 157, 161, 165, 169, 171, 172, 175-177, $184,191,200,210,211$ (MS I, 4, str. 262-276). 


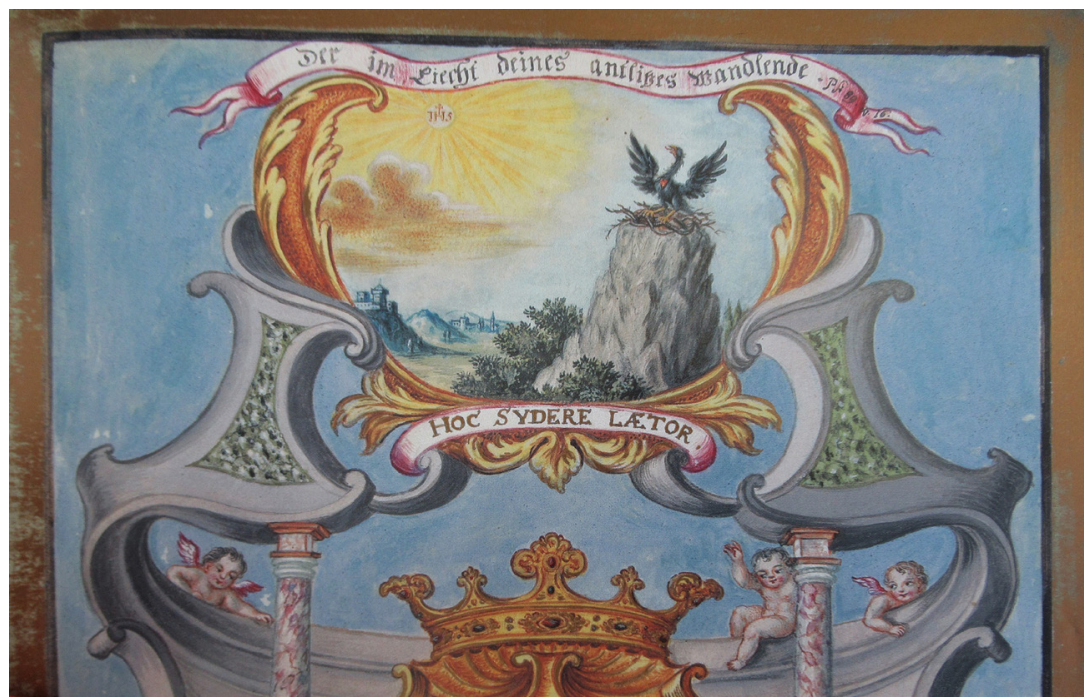

Slika 2: Simon Tadej Volbenk Grahovar, Emblem grofa Marka Ferdinanda Lichtenberga (detajl), 1740, Dizmova kronika, ARS, Ljubljana, AS 1073, I/1, fol. 287r.

Podoben motiv je za svoj emblem izbral grof Marko Ferdinand Lichtenberg (fol. 287r), le da orel ni na tleh, temveč v gnezdu, postavljenem na visoki pečini. Tudi tu dviga glavo proti soncu in razpira peruti, kot da bo ravnokar poletel (slika 2). Dejstvo, da je gnezdo zgrajeno na skali, dodaja emblemu novo vsebino. Prav tako ne smemo spregledati detajla, da je v sonce vpisan Kristusov monogram IHS z majhnim križem. Geslo Hoc sidere laetor (Pod to zvezdo je moje veselje) namesto običajnega članskega imena spremlja daljša, opisna različica: Der im Licht deines Antlitzes Wandlende (Tisti, ki hodi v svetlobi tvojega obličja). Gre za aluzijo na psalmistove besede: Blagor ljudstvu, ki pozna veselo vzklikanje, Gospod, v svetlobi tvojega obličja bodo hodili (Ps 89, 16). Geslo in akademsko ime sta usklajena $\mathrm{z}$ motivom orla, ki gleda $\mathrm{v}$ sonce, poistoveteno s Kristusom, obenem pa sta vsebinsko povezana s podobo božjega obličja, omenjenega v psalmu, na katerega se navezuje naročnikovo akademsko ime. Hkrati je seveda sonce s Kristusovim monogramom tista »zvezda«, pod katero je Lichtenberg našel »svoje veselje«.

Ob osnovni vsebini preroda $v$ Kristusu igra tokrat pomembno vlogo tudi motiv orla v skalnem gnezdu, ki ima dolgo ikonografsko tradicijo. Že Gregor Veliki poduhovljenega človeka, ki se v iskanju resnice in božje bližine umakne v samoto in višave duha, primerja z orlom, ki gradi svoje gnezdo visoko v skalah (Moralia in Job, 31, XLVII). Enako piše Psevdo Avguštin, ${ }^{19}$ ki poduhovljenega človeka primerja z orlom v skalnem gnezdu.

19 Odlomek, ki ga navaja tudi Picinelli (I, 4, 265), najdemo v spisu Meditationes liber unus oziroma Liber Medationum (PL 40, 922), pripisanem sv. Avguštinu. Znanstvena kritika spis danes pripisuje anonimnemu avtorju z zasilnim imenom Psevdo Avguštin. 
Krščanski avtorji pri alegoričnih razlagah orla v visokem gnezdu najpogosteje jemljejo za izhodišče Jobove besede: »Se orel na tvoje povelje vzdiguje visoko, da si napravi gnezdo $v$ višavi? « (Job 39, 27). Varno gnezdo v vršacih obenem simbolno predstavlja krepost in zaupanje v boga, ki najbolje varuje človeka pred sleherno nevarnostjo. Takšne razlage orla, ki gnezdi v gorah in se zazira v sonce, so v emblematiki znane že v 16. stoletju in jih najdemo tudi pri Picinelliju (I, 4, embl. 123 in 124). Skoraj gotovo je naročnik poznal emblem v knjigi nemškega polihistorja in pesnika Wolfganga Helmharda von Hohberga Lust- und Artzeney-Garten des Königlichen Propheten Davids (Regensburg 1675, fol. $89 \mathrm{r}){ }^{20} \mathrm{ki}$ ima identično geslo in sorodno ikonografijo. ${ }^{21}$ Povezava s Hohbergovim emblemom je razvidna tudi $v$ tem, da je osrednji citat njegovega epigrama prav tisti verz iz devetinosemdesetega psalma, iz katerega je Lichtenberg izpeljal svoje akademsko ime.

Emblem grofa Lichtenberga se najverjetneje navdihuje tako pri Picinelliju kot pri Hohbergu, vendar vsebuje izvirno vsebinsko nadgradnjo - skupaj z duhovitim slikovnim rebusom namreč razkriva identiteto naročnika. Ideja luči (nemško das Licht), prisotna tako $\mathrm{v}$ besedilnem kot $\mathrm{v}$ likovnem delu, je dopolnjena $\mathrm{z}$ motivom gore (nemško der Berg), ki se dviga v ospredju krajine, in s tem daje očiten namig na rodbinsko ime Lichtenberg. Kot zanimivost, ki dokazuje, da je pri vsebinski zasnovi emblemov v Spominski knjigi lahko tvorno sodeloval tudi avtor ilustracije, velja omeniti podpis slikarja, Simona Tadeja Volbenka Grahovarja, v katerem izrecno pravi, da je miniaturo naslikal in zasnoval. ${ }^{22}$

V emblemski sličici Franca Antona Oblaka barona Wolkensperga (fol. 229r) prav tako vidimo orla na visoki pečini, le da se je že dvignil iz gnezda in poletel proti soncu (slika 3). Osnovni pomen duhovnega preroda in vere v odrešenje je podoben kot v emblemu grofa Lichtenberga ter v sorodnih emblemih, ki jih najdemo v Picinellijevi knjigi (MS I, 4, embl. 123, 157, 172, 173, 177, 204). Vendar ima vsebina emblema posebno noto, izraženo v geslu Nunc procul a strepitu, hic in spe et metu (Zdaj proč od hrupa, tu v upanju in strahu). Gre za ponazoritev želje po odmaknjenosti od hrupnega vsakdanjika v bolj umirjeno poduhovljeno življenje, po iskanju bližine boga, ki se mu človek približuje v upanju in strahospoštovanju. Tudi naročnikovo člansko ime Der

20 Knjiga vsebuje nemški prevod psalmov z notnimi zapisi novih melodij, molitve, botanične ilustracije $\mathrm{z}$ alegorizirajočimi verzi ter embleme $\mathrm{z}$ epigrami v latinščini in nemščini. Tiskana knjiga ima 150 vstavljenih pergamentnih folijev z bakrorezi Georga Ch. Eimmarta. Emblemi, ki se vsebinsko povezujejo s psalmi, so na vstavljenih pergamentnih folijih zmeraj na prvi strani, medtem ko so na hrbtni strani bakrorezi rastlin.

21 V Hohbergovem emblemu so v gnezdu tudi mladiči, ki skupaj s staršem gledajo proti soncu. To vnaša nov ikonografski poudarek, saj vključuje motiv preizkušnje orličev z gledanjem v sonce. Da je v primeru Hohbergovega emblema prav ta motiv jedro emblemskega sporočila, potrjuje epigram, ki spremlja sličico.

22 "Grahover inv. (invenit) et pinx. (pinxit)«. Grahovar (1710-1774) je na ta način podpisal še petindvajset miniatur v Dizmovi kroniki. Glede na dolgoletno sodelovanje z naročniki emblemov, njegovo mojstrstvo in inventivnost lahko upravičeno sklepamo, da njegov delež pri vsebinski zasnovi ni bil majhen. Polonca Vrhunc mu pripisuje pomembno vlogo v genezi emblemov in verjame, da je dobro poznal svet simbolov (Vrhunc, 1970, 126). 


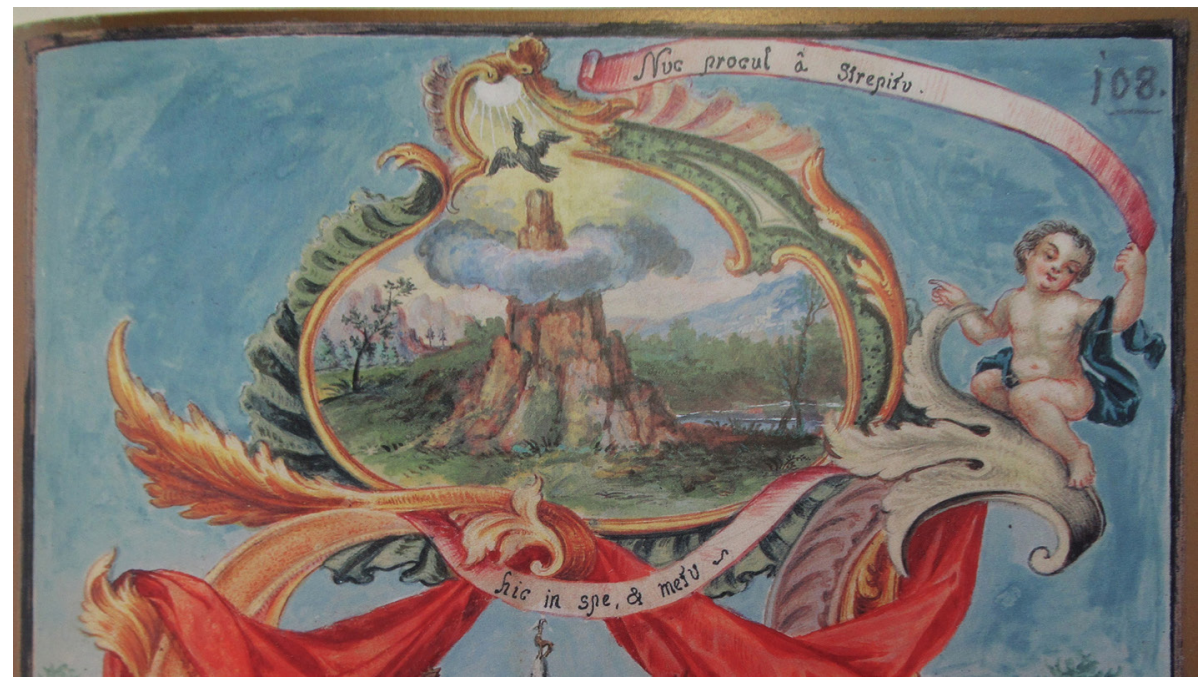

Slika 3: Simon Tadej Volbenk Grahovar, Emblem Franca Antona Oblaka barona Wolkensperga (detajl), 1724, Dizmova kronika, ARS, Ljubljana, AS 1073, I/1, fol. 229r.

Verfolgte (Zasledovani) namiguje, da se želi umakniti pred »hrupom« sveta in zaživeti bolj mirno življenje. Ideja je likovno podkrepljena z oblaki, ki zakrivajo vrh gore pred pogledom z nižin. Orel, ki vso pozornost namenja soncu, je obenem heraldična žival rodbine Wolkensperg in simbolično predstavlja naročnika. Takšno razlago potrjuje $\mathrm{v}$ slikah izražena besedna igra: gora, zavita v oblake, je aluzija na priimek Wolkensperg, $\mathrm{v}$ katerem prepoznamo besedi oblak in gora (nemško die Wolke, der Berg). Da ne bi bilo prav nobenega dvoma, je dodan še detajl rdečega srca na orlovih prsih: srce kot simbol plemiške družbe sv. Dizma na simbolni ravni orla izenačuje z baronom Wolkenspergom, ki ponosno opozarja na svoje članstvo.

V emblemu Mihaela Jožefa pl. Wallensperga (fol. 234r) je orel, ki se dviguje k soncu, naslikan nad razburkanim morjem, na katerem je jadrnica, ki se ji je uspelo zasidrati in rešiti pred brodolomom (slika 4). Varno zasidrana ladja je v evropski umetnosti tradicionalna podoba rešitve iz stiske in enako velja za področje emblematike. ${ }^{23}$ Sidro, simbol upanja, je v emblemski sličici jasno izrisano in postavljeno v prvi plan, tako da je njegov pomen še posebej naglašen. Tudi v ljubljanski Spominski knjigi se pojavi večkrat - glej embleme J. Ks. Lichtenthurna (fol. 249r), V. K. Kušlana (fol. 277r), F. A. Schmithoffna (fol. 329r) in K. B. Pettenegga (fol. 341r). V Wallenspergovem emblemu je prispodoba $\mathrm{z}$ jadrnico povezana $\mathrm{z}$ naročnikom tudi v kontekstu heraldike: na barki vihra zastava $\mathrm{z}$ družinskim grbom, orel na nebu pa je hkrati grbovna žival

23 Picinelli predstavi več kot sto emblemov z jadrnico (II, 20, embl. 49-151) in še devet, v katerih ima glavno vlogo sidro (II, 20, embl. 1-9). 


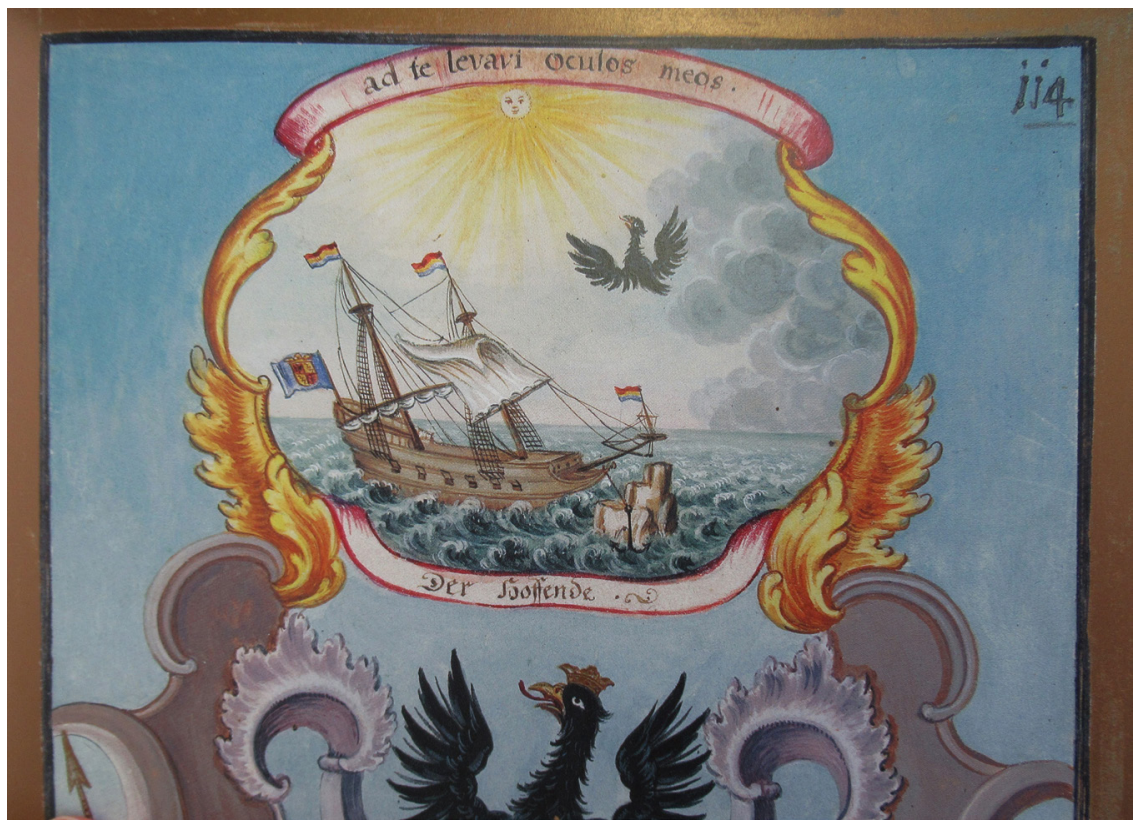

Slika 4: Simon Tadej Volbenk Grahovar, Emblem Mihaela Jožefa pl. Wallensperga (detajl), 1726, Dizmova kronika, ARS, Ljubljana, AS 1073, I/1, fol. 234r.

družine. Vsebino sličice dopolnjujeta akademsko ime Der Hoffende (Upajoči) in deviza Ad te levavi oculos meos (Svoje oči vzdigujem k tebi, Ps 123, 1). Izbrano geslo, izrečeno v prvi osebi, celo na jezikovni ravni vzpostavlja neposredno vez med orlom in naročnikom. Orla, ki se dviguje k soncu, lahko tudi tu povežemo z idejo odrešitve in preroda v Kristusu, pri čemer je zanimiva primerjava z emblemom orla in sonca v Mundus Symbolicus, ki ima identično geslo (I, 4, embl. 102). Slednji sicer ne vključuje motiva barke na morju, vendar izrecno govori o zaupanju v boga, ki nas iz stiske vodi v odrešitev.

Na miniaturi grofa Jurija Ludvika Lichtenberga (fol. 238r) se sredi morja dviguje visoka pečina, vrh katere vidimo orla, ki bo vsak hip poletel proti soncu (slika 5). Nekoliko višje, na levi, drugi orel že leti v smeri sonca. Naročnikov motto ob ideji duhovne prenove tokrat posebej poudarja odličnost duha, ki nas vodi v večno življenje, ter razkorak med vrednostjo večnega na eni in minljivega na drugi strani: Ex hac magnanimus mortalia despicit arce, tutius aethereas, ut volet inde vias ( $S$ te vzpetine, $k$ dor kvišku se vzpne, prezira umrljivo, varnejša vodi od tod pot ga v višine neba). ${ }^{4}$ Podobno

24 Topos kreposti in razkoraka med duhovno odličnostjo ter minljivostjo posvetnega življenja najdemo $\mathrm{v}$ številnih literarnih delih tako krščanskih kot antičnih avtorjev. Glede na to, da je v Lichtenbergovem geslu uporabljena besedna zveza "mortalia despicit arce«, ki jo v enakem kontekstu najdemo tudi pri Klavdijanu, je možno, da je naročnika navdihnil rimski pesnik (Panegiryus dictus Manlio Theodoro consuli XVII, 1-6). 


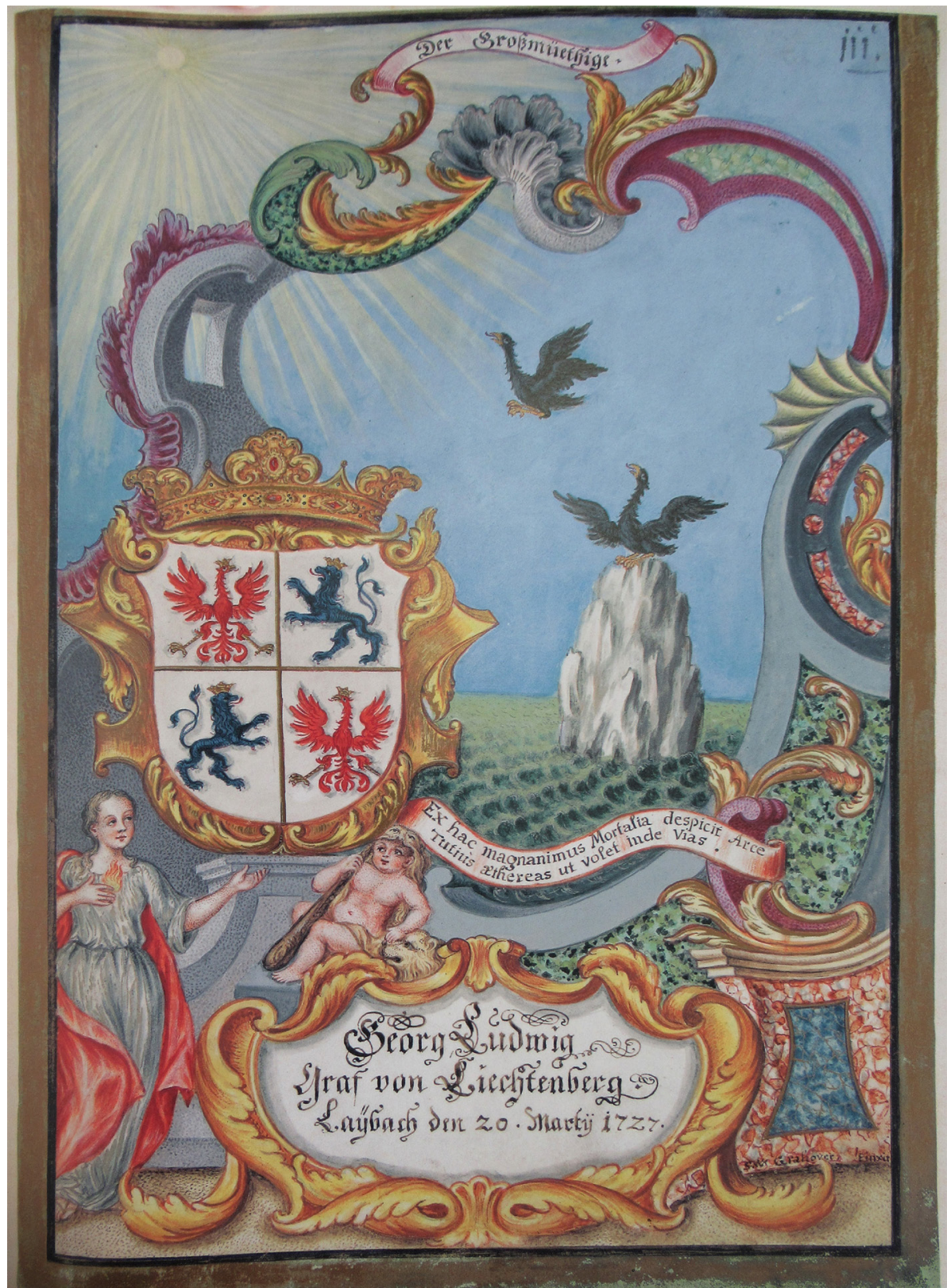

Slika 5: Simon Tadej Volbenk Grahovar, Emblem grofa Jurija Ludvika Lichtenberga, 1727, Dizmova kronika, ARS, Ljubljana, AS 1073, I/1, fol. 238r. 
kot v emblemu Franca Antona Wolkensperga je izhodišče treba iskati v Picinellijevi knjigi, kjer kar šest emblemov izraža podobno vsebino (glej zgoraj). Dejstvo, da sta na sliki upodobljena dva orla - eden že leti proti soncu, drugi pa je še v gnezdu in širi krila, da bi poletel -, lahko razumemo v povezavi z ikonografskim motivom orla, ki spodbuja svoje mladiče k letenju. Pri tem nas ne sme zmotiti dejstvo, da je mladič v gnezdu enako velik kot njegov roditelj: tak način upodabljanja je uveljavljen v renesančni emblematiki in ima osnovo tudi v naravoslovnih opažanjih. ${ }^{25}$

Motiv orla, ki z zgledom spodbuja svoje mladiče k letenju, korenini v biblijski eksegezi, v razlagi odlomka iz Mojzesove pesmi Izraelovi skali, v katerem je skrb boga za izbrano ljudstvo ponazorjena s podobo orla, ki širi peruti, uči svoje mladiče leteti in jih hkrati varuje: "Kakor orel, ki spodbuja k letu svoje gnezdo,/ kroži nad svojimi mladiči,/ širi svoje peruti, jih prestreza,/ jih nosi na svojih krilih ..." (Mz 5, 32, 11) Prispodoba je med biblijskimi eksegeti izjemno priljubljena in jo najdemo že pri cerkvenih očetih. ${ }^{26} \mathrm{Za}$ kulturno okolje ljubljanske intelektualne elite je zanimivo, da jo v eni od svojih pridig razlaga Janez Ludvik Schönleben. ${ }^{27}$ Motiv je dobro znan tudi v emblematiki: Picinelli predstavi pet emblemov s to vsebino (I, 4, embl. 175, 186, 194, 197, 214); enako število najdemo tudi v zbirki emblemov Jacoba Boscha Symbolographia (I, embl. 206, 208; II, embl. 260, 447, 615). ${ }^{28} \mathrm{~V}$ emblemih, ki jih navajata Picinelli in Bosch, je lahko alegorično sporočilo glede na geslo in kontekst različno: v okviru sakralne ikonografije gre za ponazoritev idej spodbujanja k življenju v veri in kreposti, dajanja dobrega zgleda, duhovnega vzpona in skrbi boga za krščansko občestvo, v profani pa isti motiv največkrat predstavlja skrb dobrega vladarja za svoj rod, ljudstvo in deželo, ki ji vlada.

Orel, grbovna žival grofov Lichtenbergov, skladno z uveljavljeno tradicijo v ljubljanski Spominski knjigi aludira na naročnika, osnovni motiv poti kreposti, ki je v evropski ikonografiji prisoten $\mathrm{v}$ najrazličnejših inačicah, pa ima $\mathrm{v}$ tem primeru izraženo dodatno vsebinsko noto, ki izvira iz klasične antike. Ne smemo namreč prezreti dejstva, da se emblemska sličica, ki je sicer še ujeta v kartušo, razpira in se približa odprtemu emblemu. Na mestu, kjer okvir kartuše ostaja odprt, vanjo diskretno vstopata grofov grb ter lik malega Herakleja z gorjačo in levjo kožo. Ob Herakleju stoji ženska figura z ognjenimi zublji na prsih, ki z desnico kaže nanje, z levico pa mladega junaka opozarja na orla. Čeprav žena ni označena z napisom, lahko glede na kontekst sklepamo, da ponazarja krepost: bodisi vrlino v širšem pomenu (virtus) bodisi

$25 \mathrm{~V}$ obdobju, ko mladi orli vzletijo, so že skoraj odrasli in njihova silhueta na nebu se ne razlikuje bistveno od odrasle ptice.

26 Gl. npr. sv. Ambrož (Hexaemeron, PL 14, 232) ali sv. Hieronim (Breviarium in Psalmos, PL 26, 1097).

27 Joannis Ludovici Schönleben ..., Feyertäglicher Erquick-Stunden: Das ist: Ehren-vnd Lobpredigen der lieben Heiligen Gottes... Anderer Theil, Salzburg 1670, 11.

28 Jacob Bosch, Symbolographia sive De arte symbolica sermones septem ..., J. C. Bencard, Augsburg/ Dilingen 1702. 
najpomembnejšo med krščanskimi krepostmi, to je ljubezen (caritas), ${ }^{29}$ ki je v moralni alegoriki neredko predstavljena kot lepa mladenka s plameni na prsih. Lichtenbergovo člansko ime Der Grossmütige (Velikodušni) kaže, da ženska figura v resnici pooseblja caritas. Dodatno potrditev lahko najdemo tudi v emblematiki: Picinelli v enem od emblemov motiv orla, ki spodbuja mladiče, da gledajo v sonce, poveže s podobo božje ljubezni (caritas) ter motivom razločevanja med dobrim in slabim (I, 4, embl. 93). ${ }^{30}$ Lichtenbergov emblem torej vključuje motiv Herakleja na razpotju, ki izbira med potjo kreposti na eni ter lahkotnim življenjem in zasledovanjem minljivih užitkov na drugi strani. Znani antični motiv, ki je priljubljen tudi v krščanski alegoriki zgodnjega novega veka (Panofsky, 1930, 37-173), smemo razumeti kot neposredno dopolnilo ikonografskega sporočila emblema tudi zato, ker se trak z geslom izjemoma vije na spodnjem robu sličice in se začenja tik nad Heraklejevo glavo.

Orla, ki mladiče spodbuja k letenju, si je za svojo emblemsko sličico izbral tudi baron Janez Benjamin Erberg (fol. 264r). V njej vidimo odraslega ptiča, ki je poletel z visoke skale na nabrežju morja in se dviga proti soncu, štirje mladiči pa sledijo njegovemu zgledu (slika 6).

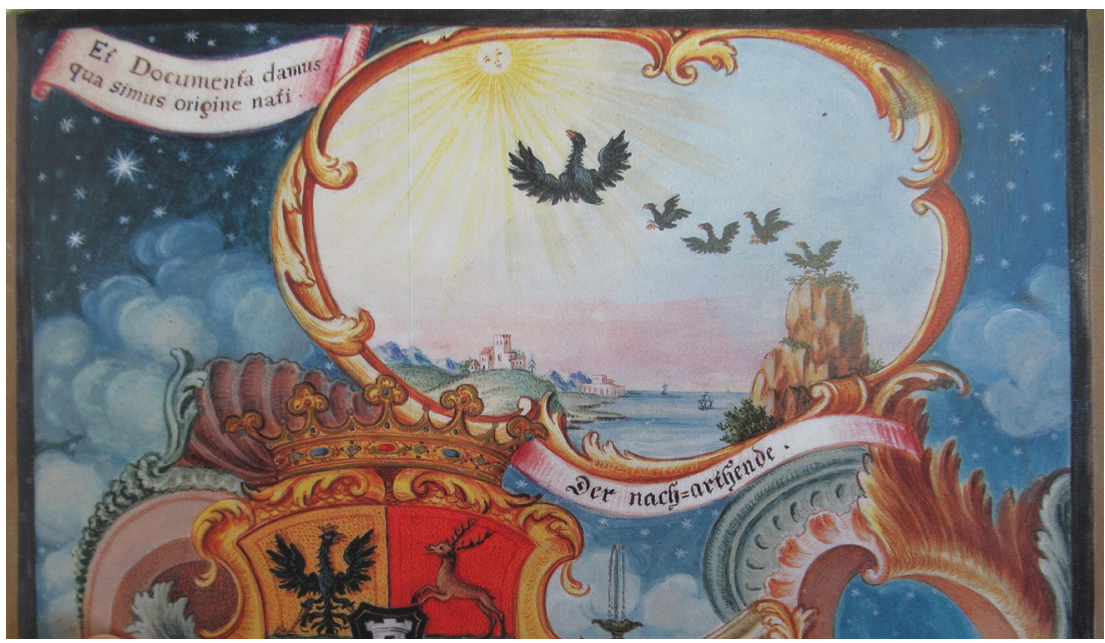

Slika 6: Simon Tadej Volbenk Grahovar, Emblem barona Janeza Benjamina Erberga (detajl), 1736, Dizmova kronika, ARS, Ljubljana, AS 1073, I/1, fol. 264r.

29 V krščanski teologiji in ikonografiji je caritas izjemno kompleksen pojem, ki po eni strani predstavlja vseobsežno božjo ljubezen, milost in velikodušnost, po drugi pa ljubezen vernikov do boga in ljubezen do bližnjega (dilectionem Dei et proximi).

30 Picinelli se pri tem sklicuje na Tomaža Akvinskega in njegovo misel, da smo ljudje podvrženi dobremu in slabemu ter da nas božja ljubezen (caritas) vodi k zmagi dobrega. Misel podkrepi z besedami sv. Avguština, ki govori o ognju božje ljubezni, v kateri se dobro razloči od zlega. S tem daje neposredno izhodišče tako za povezavo božje ljubezni z ognjem kakor tudi za motiv preizkušnje in izbire med dobrim in zlim, kar je osnovna vsebina emblema. 
Tokrat so mladiči, v nasprotju z realističnim pristopom, upodobljeni opazno manjši od svojega očeta. Vendar se z morebitnimi vsebinskimi implikacijami ne kaže prenagliti: deloma lahko razliko v velikosti pripišemo kompozicijski zasnovi miniature, saj orliči vzletajo s skale v daljavi in sledijo staršu, ki se približuje prednjemu planu slike, zato je razumljivo večji. Ob tem je treba upoštevati še ikonografsko tradicijo renesančnih emblemov, v katerih so mladiči zaradi lažjega razumevanja motiva neredko namenoma upodobljeni manjši od staršev. ${ }^{31}$ Baronovo izbrano člansko ime Der Nachartende (Posnemajoči) se nanaša na mladiče, geslo Et documenta damus, quia simius origine nati (Sami smo živi dokaz korenin, ki iz njih smo pognali) ${ }^{32}$ pa vsebino emblema zaokroži z mislijo, da mladiči s tem, ko sledijo zgledu staršev, dokazujejo, da so njihovi vredni nasledniki. Geslo priča, da gre za razmeroma pogosto kombinacijo obeh ikonografskih motivov spodbude $\mathrm{k}$ letenju in preizkušnje mladih orličev, ki jih oče sili, da gledajo v sonce. ${ }^{33}$

Motiv korenini v antični tradiciji in že Aristotel v Zgodovini živali (IX, 34) piše, da naj bi orel svoje mladiče silil gledati v sonce. Če tega ne zmorejo, jih zavrže, saj je njihova šibkost dokaz, da niso njegovi pravi potomci. Nekatere manjše ujede naj bi namreč v orlovo gnezdo poskušale podtakniti svoja jajca in s tem zagotoviti preživetje lastnega zaroda v varstvu kralja ptic. A ker noben ptič, razen orla, ne more nemoteno gledati v sonce, orlovski starši z omenjeno preizkušnjo odkrijejo podtaknjena piščeta. O nenavadni skušnji poleg Aristotela poročajo tudi Plinij v Naravoslovju (X, 10), Ajlijan v Značilnostih živali (II, 26 in IX, 13), Mark Anej Lukan v pesnitvi Farzalija (IX, 902-906) ter drugi antični avtorji. Motiv v krščanskem duhu alegorično razlaga že sv. Ambrož (natančneje Psevdo Ambrož) v pridigi o Salomonu (Sermo 46. De Salomone, PL 17, 718). Med srednjeveškimi enciklopediki pa Izidor Seviljski v Etimologijah (XII, 7,11 ), na katerega se sklicujejo poznejši pisci. Neobičajna epizoda je redno predstavljena tudi v bestiarijih, pri čemer najpogostejša alegorična razlaga pravi, da so orliči, ki gledajo v sonce, podoba vernikov, ki v polni meri sprejemajo božji nauk in so zato deležni preroda. Mladiči, ki tega ne zmorejo, predstavljajo slabe kristjane, grešnike ali nevernike. Motiv je pogost tudi v emblematiki, kjer osnovna vsebina preizkušnje dobi številne nove simbolne razlage. ${ }^{34}$

31 Glej: Bosch, 1702, II, embl. 1014.

32 Geslo je zaključek verza iz Ovidijevih Metamorfoz: "Inde genus durus summus experiensque laborum / et documenta damus, quia simius origine nati« (I, 414-415).

Verzi so navedeni v prevodu Barbare Šega Čeh: Publij Ovidij Nazon, Metamorfoze I.-III., Ljubljana 2013. Gantar verz prevaja nekoliko drugače: »Sami smo živ dokaz tvari, ki iz nje smo rojeni. (Kastelic, 2001, 204)

33 Zaradi vsebinske povezanosti obeh motivov je njuno stapljanje razumljivo in se uveljavi že v srednjem veku. Kljub temu da antični viri preizkušnjo vida postavljajo v čas, ko so mladiči še puhasti in ne morejo leteti, krščanska ikonografija ta detajl pogosto prezre oziroma se raje opre na poznejše zapise $\mathrm{v}$ posameznih bestiarijih, kjer beremo, da orel preizkušnjo vida pri mladičih opravi šele, ko lahko letijo. Skupaj z njimi poleti proti soncu: tiste, ki mu sledijo in zmorejo gledati v sonce, prizna za svoje, ostale zavrže. (Glej poglavje o orlu v bestiariju Guillauma le Clerca, Bestiaire divin, sr. 13. st., Bodleian Library, MS. Douce 132.)

Picinelli predstavi devet emblemov s to vsebino (I, 4, embl. 89-97). 
Vpisni list barona Franca Rudolfa Wolkensperga (fol. 369r) krasi celostranski odprti emblem s pogledom na gorsko krajino, ovito v meglice, skozi katere v nebo štrlijo le najvišji vršaci (slika 7). Na enem od njih je gnezdo z orličem, nekoliko bližje gledalcu pa leti odrasel orel, ki se oddaljuje od gnezda. V obroču oblakov je na nebu sonce Z vrisanim božjim očesom, s čimer je naglašena njegova krščanska simbolika. Nad mladičem, ki razpira peruti in dviguje glavo k sončevi luči, je v ravni črti proti soncu izpisano geslo: Auxilium de coelo (Pomoč z neba). V prvem planu slike sta ob naročnikovem grbu in kartuši s podatki o vpisu naslikani poosebitvi pravičnosti in slave. Slava $\mathrm{v}$ rokah drži širok bel trak z baronovim članskim imenom: Der Verlassene und doch Beglückte (Zapuščeni, pa vendar osrečeni).

Slika, predvsem pa geslo in akademsko ime kažejo, da gre za izvirno različico motiva mladega orla, ki se uči leteti. Na Grahovarjevi miniaturi je starš že zletel iz gnezda in mladiču daje zgled, vendar mu orlič ne sledi, kot bi pričakovali glede na ustaljen tip likovnih realizacij v emblematiki. ${ }^{35}$ "Zapuščen « v gnezdu izteguje glavo proti soncu, ki simbolizira Kristusa, kakor da v svoji šibkosti prosi za pomoč z neba. To slikar v likovnem in vsebinskem pogledu poudari $z$ dvema elementoma: starš se oddaljuje od gnez$\mathrm{da}, \mathrm{s}$ čimer stopnjuje dramsko napetost, na drugi strani pa $\mathrm{z}$ neobičajnim načinom izpisa gesla umetnik vzpostavi vizualno vez med mladičem in soncem. Bralec zlahka razume, da bo mladič, ki ni zbral poguma, da bi sledil staršu, vsak trenutek deležen pomoči: bog, v katerega zaupa, mu bo vlil srčnosti, da poleti. Ob tem velja izpostaviti, da Janez Ludvik Schönleben v že omenjeni razlagi prispodobe o orlu, ki uči mladiče leteti, izrecno poudarja "pomoč z neba «, božjo ljubezen in milost, ki duhu pomagata, da se dvigne kvišku. Govori tudi o opogumljanju in spodbujanju, pri čemer navaja odlomke iz pridige sv. Bernarda (Pridiga o Kristusovem vnebohodu) in pridige na isto temo, ki jo je napisal njegov učenec opat Guerric d'Igny. ${ }^{36} \mathrm{~V}$ emblemu barona Wolkensperga je poudarek prav na zaupanju v boga, ki ljubeče skrbi za vse svoje »otroke«, jim vliva pogum in kaže pot. Poosebitvi v sprednjem delu slike vsebino dopolnjujeta s sporočilom, da je na poti, ki vodi v večno slavo, pomembna pravičnost in $\mathrm{z}$ njo povezana ljubezen do resnice. Pravilnost razumevanja emblemskega sporočila potrjujeta položaj in način upodobitve obeh personifikacij: Pravičnost, ki nas vodi v življenju, se naslanja na baronov grb in se s pogledom osredotoča nanj, Slava pa dviguje svoj pogled v nebo, kamor se pne trak s članskim imenom naročnika. Dejstvo, da ima figura pod nogami zemeljsko oblo, da je bosa in oblečena v preprosto belo obleko, kaže, da ne gre za običajno idejo slave, temveč za krščansko poosebitev večne slave. Kot že v primeru Franca Antona Wolkensperga vršaci z oblaki tudi tokrat namigujejo na rodbinsko ime.

35 Kastelic ob opisu dodaja, da orel leti v dolino po plen $(2001,252)$, čeprav za takšno razlago v emblemu ni nobene ikonografske osnove in tudi sicer v emblematiki nima ustreznih vzporednic.

36 Schönleben večkrat uporabi priljubljen obrazec »sursum corda«, ki redno nastopa v krščanski liturgiji $(1670,11)$. Krščanski pisci besedno zvezo najpogosteje uporabljajo v pridigah, v kontekstu opogumljanja vernikov in spodbujanja srčnosti. 


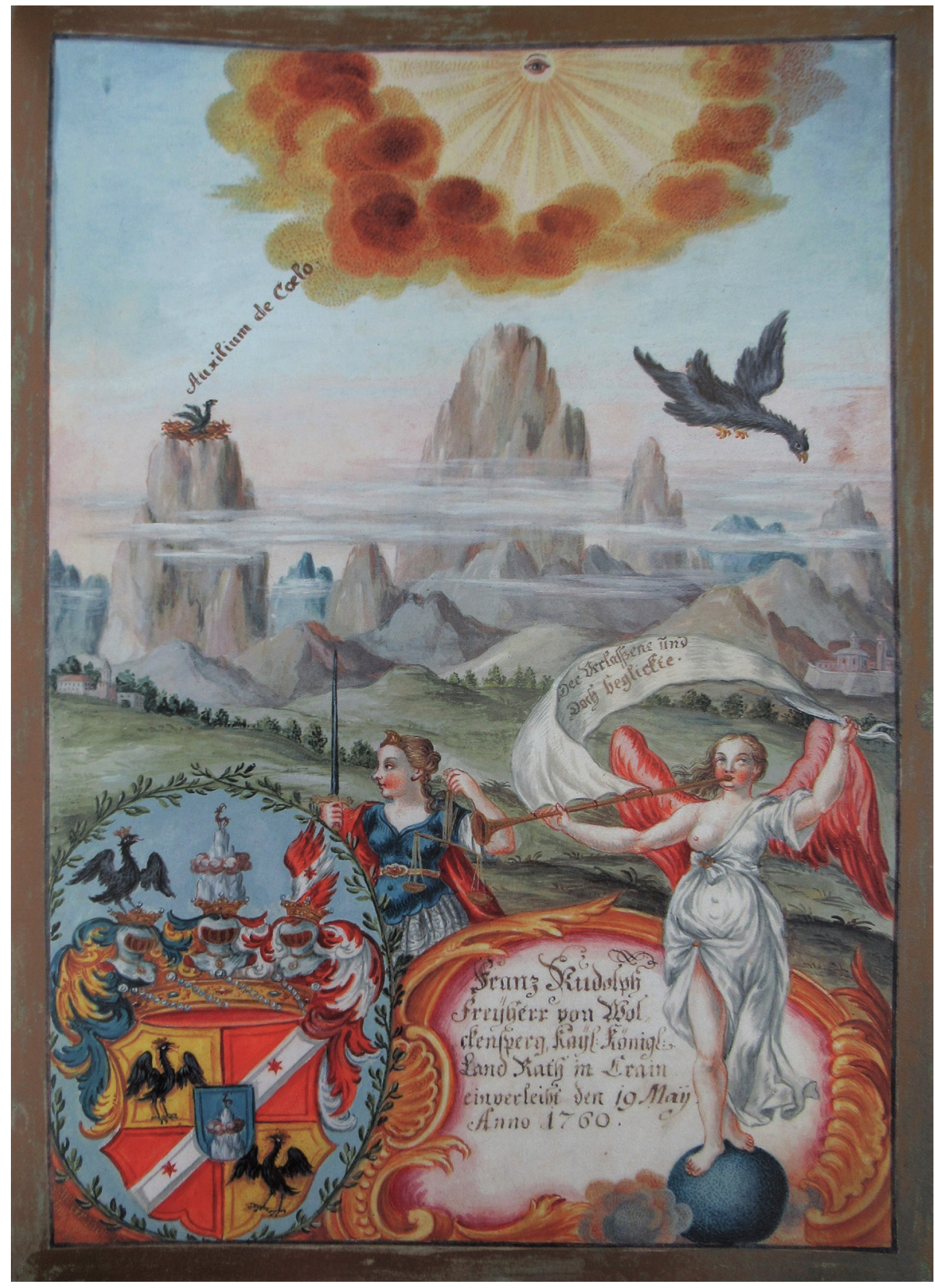

Slika 7: Simon Tadej Volbenk Grahovar, Emblem barona Franca Rudolfa Wolkensperga, 1760, Dizmova kronika, ARS, Ljubljana, AS 1073, I/1, fol. 369r. 


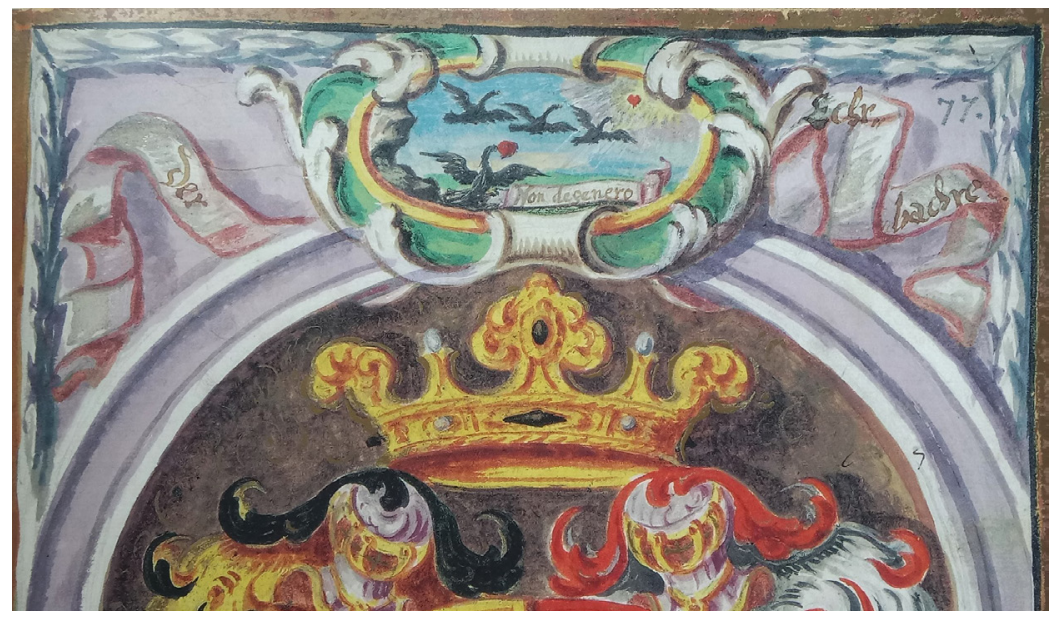

Slika 8: Bartolomej Ramschissl(?), Emblem Franca Mihaela pl. Erberga (detajl), 1709, Dizmova kronika, ARS, Ljubljana, AS 1073, I/1, fol. 161r.

Motiv orla, ki mladiče spodbuja k letenju, je z nekoliko spremenjenim vsebinskim poudarkom ob svojem vpisu v Dizmovo družbo izbral tudi Franc Mihael pl. Erberg (fol. 161r) (slika 8). V emblemski sličici trije orli letijo proti soncu, medtem ko je četrti še na tleh in razpira peruti, da bi poletel. Ob tem ne moremo spregledati, da tokrat vlogo sonca deloma privzema veliko rdeče srce: naslikano je tik pred soncem, ujeto v njegov svetlobni sij, kot da tudi samo izžareva svetlobo. Živordeče srce, simbol družbe sv. Dizma, lahko opazimo tudi v kljunu orla, ki se pripravlja, da bo vzletel. Na napisnem traku znotraj kartuše je kratko geslo Non degenero (Ne spridim se), na daljšem zunaj nje pa je zapisano akademsko ime Der Ehrbahre (Častivredni). Motto kot osrednjo temo izpostavlja preizkušnjo orličev. Geslo ni izvirno, temveč povzeto po emblemu Karla Emanuela I., vojvode Savojskega, ki govori o tem, da je vojvoda vreden sin svojega očeta (MS I, 4, embl. 97). Picinellijeva razlaga pokaže, da ne gre samo za identično geslo, temveč je tudi vsebina emblema precej podobna, le da je pri Erbergu dopolnjena z namigom na njegovo članstvo v Dizmovi družbi. Če ne bi motto očitno kazal na preizkušnjo mladičev, bi lahko pomislili, da je glavna tema sličice spodbujanje mladih orlov k letenju. V resnici gre za stapljanje obeh motivov, pri čemer je zaradi gesla in akademskega imena v prvem planu ideja častivrednega sledenja zgledu prednikov. Izvirna nadgradnja osnovne ikonografije je pri Erbergovem emblemu vidna v tem, da se znak Dizmove družbe simbolično povezuje s soncem, obenem pa enako srce drži tudi orel, ki se pripravlja za vzlet. S tem se ideja emblema preoblikuje v duhu, ki ga v Spominski knjigi večkrat zasledimo: sledenje načelom družbe sv. Dizma in izpolnjevanje skupnih zavez prispevajo k njeni odličnosti, hkrati pa plemenitijo vsakega posameznega člana. Motiv skušnje orlovih 
mladičev je torej domiselno cepljen na temo pripadnosti plemiški družbi in njenim načelom, predvsem pa sledenju zgledov starejših članov.

Dejstvo, da so vsi štirje orli videti kot odrasle ptice, je v tem primeru najverjetneje zavestna odločitev, povezana z emblemskim sporočilom. Orel, ki drži v kljunu živordeče srce, simbolno predstavlja naročnika, kar potrjujejo tudi člansko ime, geslo in povezava s heraldičnim orlom Erbergov. Franc Mihael Erberg - Častivredni - z vključitvijo stiliziranega srca sporoča, da sledi vzoru starejših članov Akademije Zedinjenih. Kako spretno je neznani avtor sličice (verjetno Trostov učenec Bartolomej Ramschissl) naglasil emblemsko sporočilo, postane v celoti vidno ob primerjavi z Dolničarjevo skico, na kateri trije enako veliki orli s srci v kljunih letijo proti večjemu srcu na nebu (Konceptna knjiga, sl. št. 75). Slikar je trem orlom dodal četrtega, ki ga je s postavitvijo v ospredje kompozicijsko in velikostno izpostavil, hkrati pa mu je kot edinemu dodelil srce, ki ga dviguje kvišku. ${ }^{37}$ Slikarjev poseg daje emblemu nov vsebinski poudarek in priča o njegovi aktivni vlogi v sami ikonografski zasnovi. To ni edini primer, ko umetnik dejavno sooblikuje emblemsko sporočilo - Andrej Trost je svobodno predrugačil Dolničarjevo skico orla za Watzenbergov emblem (glej zgoraj) in zanesljivo preoblikoval skicirani koncept vsaj še v primeru emblema za Janeza Štefana Florjančiča (fol. 73r), kjer je poseg z ikonografskega vidika še radikalnejši (Germ, 2017, 156-157). Vsebinski poudarek, ki ga je s svojo intervencijo izpostavil miniaturist, pojasni tudi, zakaj orel, ki vzleta, ni upodobljen kot mladič. Osnovna ideja pristnosti rodu in častivrednosti nasledstva (ki prevladuje v emblemu Emanuela Savojskega) se, kot rečeno, poveže s priložnostjo grofovega vpisa v plemiško družbo sv. Dizma in poudarja, da se hoče izkazati vrednega zaupanja akademskih kolegov, ki so ga sprejeli medse.

Odprti emblem grofa Volfa Engelberta Ignaca Auersperga (fol. 306r) kaže obmorsko pokrajino z mogočnimi ruševinami, pred katerimi stojijo štirje moški temne polti, ki z loki streljajo na orla. Kralj ptic leti k soncu in je tako visoko na nebu, da ga puščice mož s perjanicami ne morejo doseči. Jalovost njihovega početja potrjuje geslo na napisnem traku v orlovih krempljih: Irrideo tela (Ne zmenim se za strelice). Grofovo člansko ime Der Hochschwebende (Visoko lebdeči) zaokroži podobo orla, ki leta višje kot vse ptice in mu puščice ne morejo do živega (slika 9).

Že stari Grki in Rimljani so verjeli, da orel leta tako visoko, da mu niti strele ne morejo škodovati. Nasprotno, ptica, ki spremlja vladarja bogov, lahko celo nosi Zevsove strele v svojih krempljih..$^{38}$ Motiv orlovega visokega leta se v krščanski ikonografiji

$37 \mathrm{Ob}$ tem je avtor emblemske sličice vnesel še eno spremembo: v Dolničarjevi skici Erbergovega emblema je namesto sonca na nebu narisano shematizirano srce, slikar pa je srce obdal s sončevim sijem ter ga tako likovno kot ikonografsko najtesneje povezal s soncem.

38 Orla v povezavi z Zevsom in njegovo strelo omenja že Pindar v Pitijski odi (I, 5-10), večkrat pa ga srečamo v rimskem pesništvu, na primer v Ovidijevih Metamorfozah (X, 155), Horacijevih Odah (IV, 4) ali Vergilijevi Eneidi (V, 252). O orlu in streli piše tudi Plinij v Naravoslovju (X, 4, 15). Orla, ki v krempljih drži strelo, najpogosteje najdemo na helenističnih kovancih Ptolemajske dinastije in seveda na rimskih novcih. V Rimu je orel s strelo eden najpomembnejših državnih simbolov. 


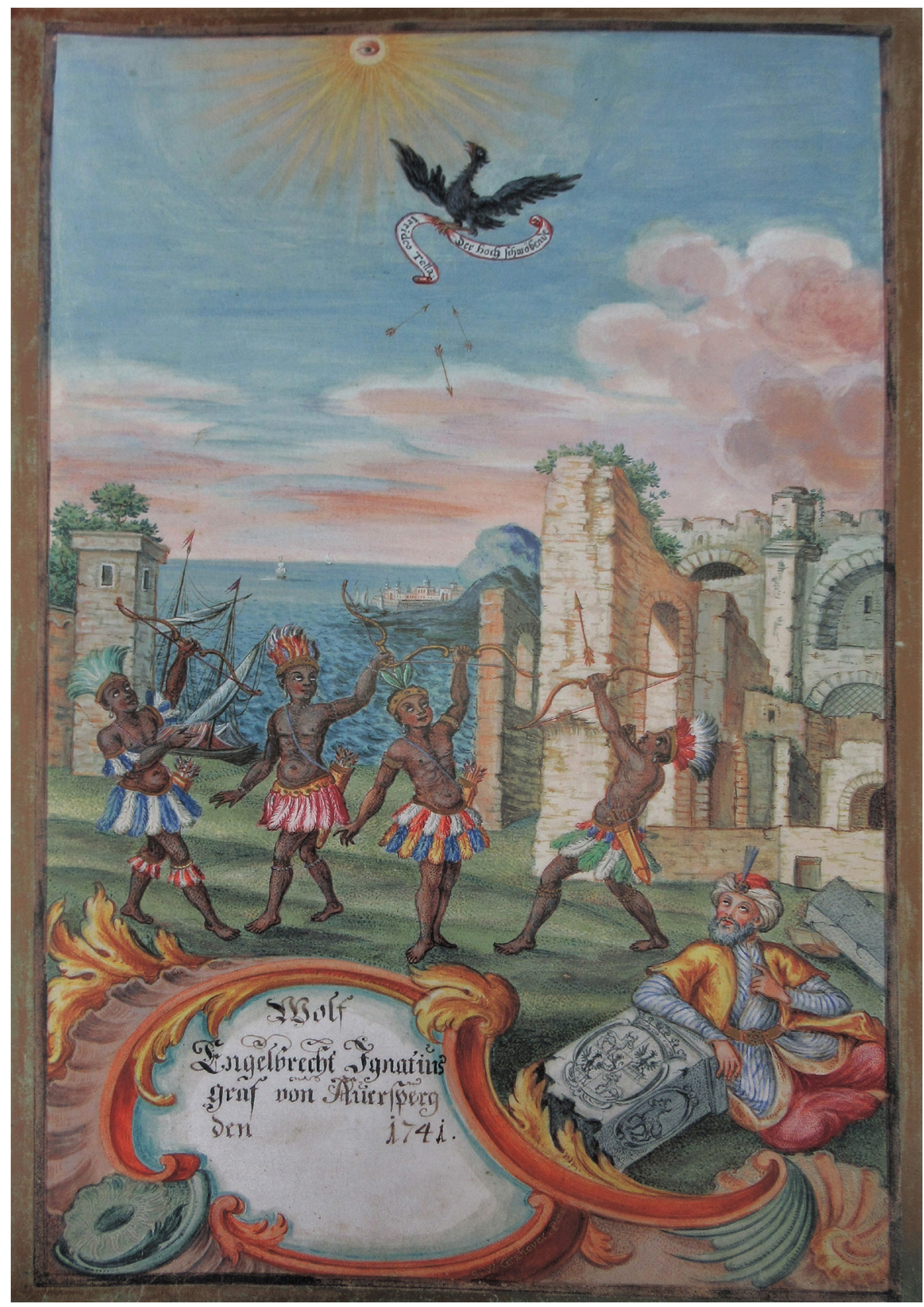

Slika 9: Simon Tadej Volbenk Grahovar, Emblem grofa Volfa Engelberta Ignaca Auersperga, 1741, Dizmova kronika, ARS, Ljubljana, AS 1073, I/1, fol. 306r. 
uveljavi predvsem s sv. Avguštinom, ki intelektualno zahtevnost Janezovega evangelija v odnosu do ostalih treh evangelijev primerja $\mathrm{z}$ letom orla, s čimer dobi motiv alegorično dimenzijo posebne duhovne moči in odličnosti. ${ }^{39}$ Obe tradiciji se zlijeta v emblematiki, kjer je motiv zelo pogost in ima celo paleto simbolnih vsebin. V sonce je - kot pri mnogih emblemih Dizmove kronike - vrisano božje oko. S tem je vsebinsko izhodišče emblema nedvoumno povezano z ikonografijo preroda $\mathrm{v}$ Kristusu, vendar ima sporočilo emblema tokrat bolj izpostavljeno idejo vzvišenosti nad nevarnostmi in tegobami tega sveta: kdor stremi k višjim ciljem, najde zavetje v bogu in mu zlo ne pride do živega.

Ob tem ostaja odprto vprašanje, zakaj je slika orla, ki ga puščice ne dosežejo, dopolnjena $\mathrm{z}$ eksotičnim motivom »indijanskih lokostrelcev «. ${ }^{40} \mathrm{~V}$ emblemskih knjigah takšne podobe ne najdemo - sličice se omejujejo na poenostavljeno predstavitev orla, ki leti višje od puščic. Ključ do razumevanja ikonografskega oreha lahko najdemo v Simbolografiji Jacoba Boscha, v emblemu, posvečenem ideji plemenitega državnika, ki je vzvišen nad obrekovanji in spletkami (III, embl. 1025). Bakrorez z orlom in puščicami je namreč pospremljen z geslom Haud ullae potuere (Nikakor ne more), avtorjeva notica ob emblemu pa opozarja, da je motto povzet po Vergiliju. V resnici gre za besede iz verza, ki ga najdemo v Georgikah, ko pesnik ob omembi Indije govori o drevesih, katerih krošnje so tako visoke, da nobena puščica ne more poleteti do njihovega vrha, pa čeprav so domorodci izvrstni lokostrelci. ${ }^{41}$ Motiv orla, ki ga puščice ne dosežejo, je torej pri Boschu povezan z Indijo in Vergilijevo prispodobo o višini tamkajšnjih dreves, pictura pa je skladno z lapidarnostjo kompozicij, ki je značilna za emblemske sličice v Boschevi enciklopediji, omejena na najnujnejše likovne prvine: orla v letu in puščice pod njim.

Grahovar je imel na voljo celo stran in je sporočilo Auerspergovega emblema dopolnil s slikovitim prizorom »indijanskih« lokostrelcev, ki so v resnici Indijci, o katerih piše Vergilij. Slikar in naročnik sta lahko likovne zglede za eksotičen motiv »Indijancev« našla v različnih virih - od alegoričnih predstavitev kontinentov, kjer spremljajo poosebitev Amerike, do ilustracij v geografskih atlasih ali zgodovinskih zapisih o Novem svetu. Zagotovo gre pri tem tudi za odmev takrat modnega navdušenja nad eksotičnimi deželami. Hkrati lahko z veliko verjetnostjo zapišemo, da je posredno prisotna tudi aluzija na antično zanimanje za čudesa Orienta, kot ga je v pesniških podobah naslikal Vergilij.

Turški paša, ki sedi ob kartuši in se lagodno naslanja na prevrnjen kamniti blok z vklesanim grbom rodbine Auersperg, ni neposredno vključen v sporočilo emblema, razumemo pa ga lahko kot izraz istega navdušenja nad eksotičnim, ki ga izpričujejo

39 Sv. Avguštin, In Evangelium Joannis tractatus, XXXVI, 5, PL 35, 1668.

40 »ndijanci«s peresnimi kronami in kratkimi pisanimi krilci, oboroženi z loki in puščicami, so značilni predstavniki Amerike, poimenovanje pa izvira iz Kolumbovega zmotnega prepričanja, da je odkril Indijo. Vse od 16. stoletja jih najdemo v alegoričnih prizorih (predvsem v okviru ikonografije štirih kontinentov), v ilustriranih knjigah s področja geografije in zgodovine, v potopisnih delih in drugje.

41 "Aut quos Oceano propior gerit India lucos, / Extremi sinus orbis: ubi aera vincere summum/ Arboris haud ullae jactu potuere sagittae?/ Et gens illa quidem sumits non tarda pharetris«(Georgike II, 122-125). 
»Indijanci« v fantazijski opravi. Slikoviti orientalski motivi z moškimi in ženskimi liki v otomanski noši se pojavljajo tudi v nekaterih drugih emblemih Dizmove kronike, na primer v emblemu barona Marka Antona Bilichgrätza (fol. 320r) ali barona Karla Leopolda Rosettija (fol. 357r). Vsi liki v otomanskih oblačilih se umeščajo v modno tradicijo t. i. turkerij, ki so $\mathrm{v}$ tem času priljubljene $\mathrm{v}$ številnih evropskih deželah, seveda tudi na ozemlju današnje Slovenije. V primeru turjaških knezov bi turškega pašo lahko razumeli kot namig na slavno zgodovino naročnikovih prednikov, ki so se borili proti Turkom. Slednji so bili še ne tako dolgo nazaj huda nevarnost za Kranjsko in velik del Srednje Evrope, dokler niso bili uničujoče poraženi v bitki pri Sisku leta 1593. V njej je pomembno vlogo odigral slavni prednik naročnika Andrej Auersperg (1557-1593), ki se je s svojim junaštvom zapisal v zgodovino. Kranjska poslej ni bila več tako neposredno ogrožena, saj je otomanski imperij ofenzivo preusmeril bolj na sever proti cesarski prestolnici na Dunaju. Posledično so se v slikarstvu Turki iz krvoločnih vojščakov pogosto prelevili v eksotične like, ki gledalce razveseljujejo s svojo slikovito nošo.

$\mathrm{V}$ nizu emblemov z motivom orla in sonca v ljubljanski Spominski knjigi pripada emblemu barona Karla Jožefa Valvasorja (fol. 294r) posebno mesto: je namreč eden od redkih, ki ima ob geslu in članskem imenu še dodatno pojasnilo v smislu kratkega epigrama (slika 10). Izbrano akademsko ime Der Verneuerte (Prenovljeni) in geslo Formosus renascens (Lepši ob ponovnem rojstvu) tako dopolnjujeta verza: Ex senio rediturus adit Iovi armiger aetheram / Solis ubi hanc puro sidere flamma cremat (Jupitrov orel se vrača iz starosti in $k$ nebu se vzpenja, tja, kjer sončni ga plamen s prečistim sijajem

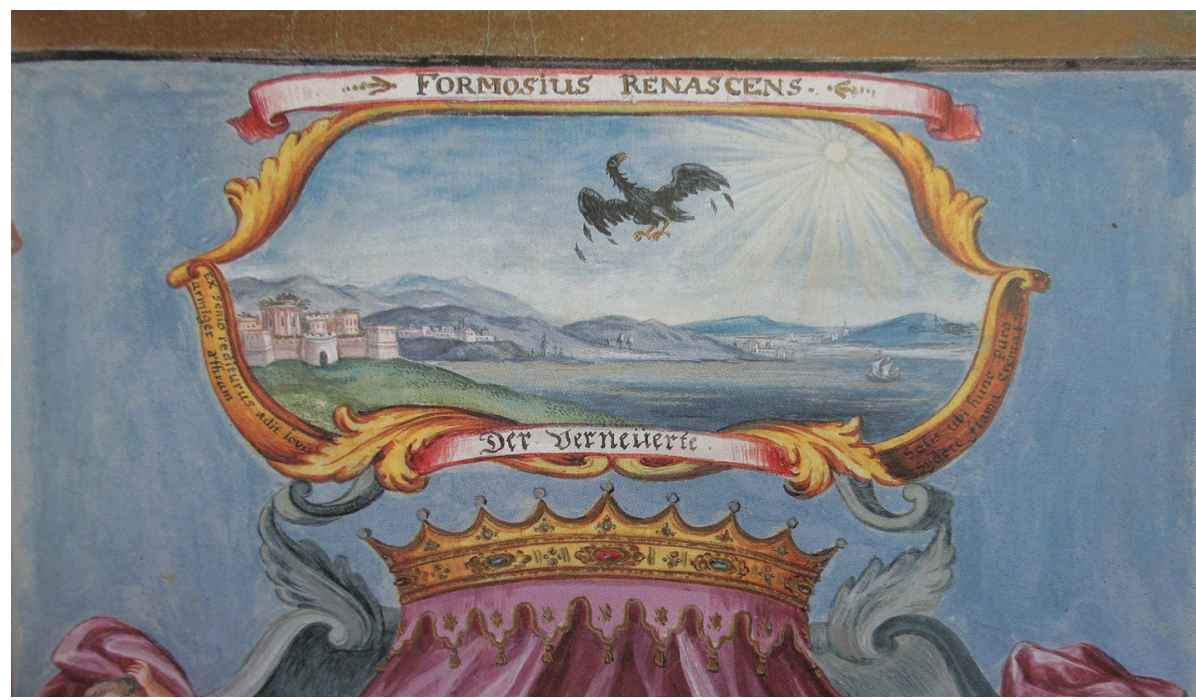

Slika 10: Simon Tadej Volbenk Grahovar, Emblem barona Karla Jožefa Valvasorja (detajl), 1740, Dizmova kronika, ARS, Ljubljana, AS 1073, I/1, fol. 294 r. 
objame). Motiv preroda je izrecno izpostavljen; v ikonografskem pogledu je sporočilo emblema tako jasno, da o njem ne bi bilo treba izgubljati besed, če ne bi v obstoječi ikonografski interpretaciji prišlo do nepričakovanega zdrsa. Avtor ikonografskega kataloga namreč opisu emblemske sličice doda kratko obrazložitev: „Slika orla v antitetični obliki potrjuje devizo« (Kastelic, 2001, 217). Očitno je njegovo pozornost pritegnilo dejstvo, da orel v nasprotju z ostalimi emblemi v Dizmovi kroniki ni naslikan $\mathrm{v}$ letu proti soncu, ampak leti proč od njega, pri čemer mu iz peruti izpadajo peresa. Kasteličeva trditev je problematična že v izhodišču, saj je v neskladju s samo teorijo renesančnega emblema: vsi nosilci sporočila morajo biti organizirani po načelu medsebojnega dopolnjevanja, tako da skupaj izoblikujejo homogeno emblemsko vsebino. $\mathrm{Z}$ drugimi besedami, besedilni in slikovni del emblema ne moreta biti v antitetičnem razmerju na način, kot predlaga Kastelic.

V emblemu pravzaprav ni nobene antitetičnosti, saj pictura smiselno ilustrira razširjeno različico motiva orlovega preroda, kakršno ponuja že Fiziolog. Ostareli orel, beremo, poleti k soncu, ki mu sežge staro perje ter razblini meglico v motnih očeh, nato pa se trikrat potopi v bistro vodo, iz katere vzleti popolnoma prerojen. Verodostojnost trditve avtor Fiziologa podkrepi z besedami psalmista: "[...] kakor orlu se obnavlja tvoja mladost.«(Ps 102, 5), ${ }^{42}$ ob tem pa dodaja alegorično razlago: »Kadar $t i$ oblačila starega človeka postanejo težka in oči tvojega srca motne, poišči izvir duha, živi vir, ki je Gospodova beseda [...] in poleti v višave proti soncu pravice, Jezusu Kristusu ter se osvobodi oblačil starega človeka in njegovega početja« $(\mathrm{I}, 6) .{ }^{43}$ Čeprav epigram, v katerem je kralj ptic izrecno imenovan Jupitrov orel, izpostavlja antično konotacijo, je prevladujoča simbolika krščanska. Grška in rimska ikonografija orla namreč ne poznata motiva pomladitve $\mathrm{z}$ letom proti soncu, ki orlu sežge stara peresa, da odpadejo in namesto njih zrastejo nova. Šele v renesančni emblematiki pride do povezovanja Jupitrovega orla, ki se v letu najbolj približa soncu, z motivom pomladitve, ki izhaja iz Fiziologa in svetopisemske tradicije. Pictura Valvasorjevega emblema posebej izpostavi epizodo z ožganimi peresi, ki odpadajo z orlovih kril. Motiv je v emblematiki dobro znan, embleme s to vsebino pa najdemo tako v Picinellijevi zbirki $(\mathrm{I}, 4,160)$ kot v Boschevi enciklopediji. Res je, da je izpadanje peres večkrat upodobljeno v trenutku, ko se orel približa soncu (npr. Claude Paradin, Devises Heroïques, Lyon 1551, 172; Bosch III, embl. 39), čeprav je tudi različica $z$ orlom, ki leti stran od sonca, dokaj pogosta (npr. Camerarius, III, embl. 14; Bosch, I, embl. 853). ${ }^{44}$

42 Za prepričanje, da se je orel sposoben pomladiti, glej tudi Izaijo:»[...] tisti pa, ki zaupajo v Gospoda, / obnavljajo svojo moč, / vzdigujejo trup kakor orli« (Iz 40, 31).

43 Za celotno poglavje o orlu glej: Zucker, 2005, 78.

44 Bosch ob sličici orla, ki je obrnjen stran od sonca in mu iz kril odpadajo peresa, ponudi tri gesla: Renovata juventus, Et damna juvabunt in Donec renover (Bosch I, embl. 853). Izrecno utemeljitev za motiv orla, ki mu stara peresa izpadejo potem, ko se že oddaljuje od sonca, najdemo med drugim v priljubljeni enciklopediji Bartolomeja Angleža O lastnostih stvari (ok. 1342-1347), kjer piše, da vročina sonca orlu razširi pore, zaradi česar mu začnejo peresa izpadati (De proprietatibus rerum, XII, 1). 


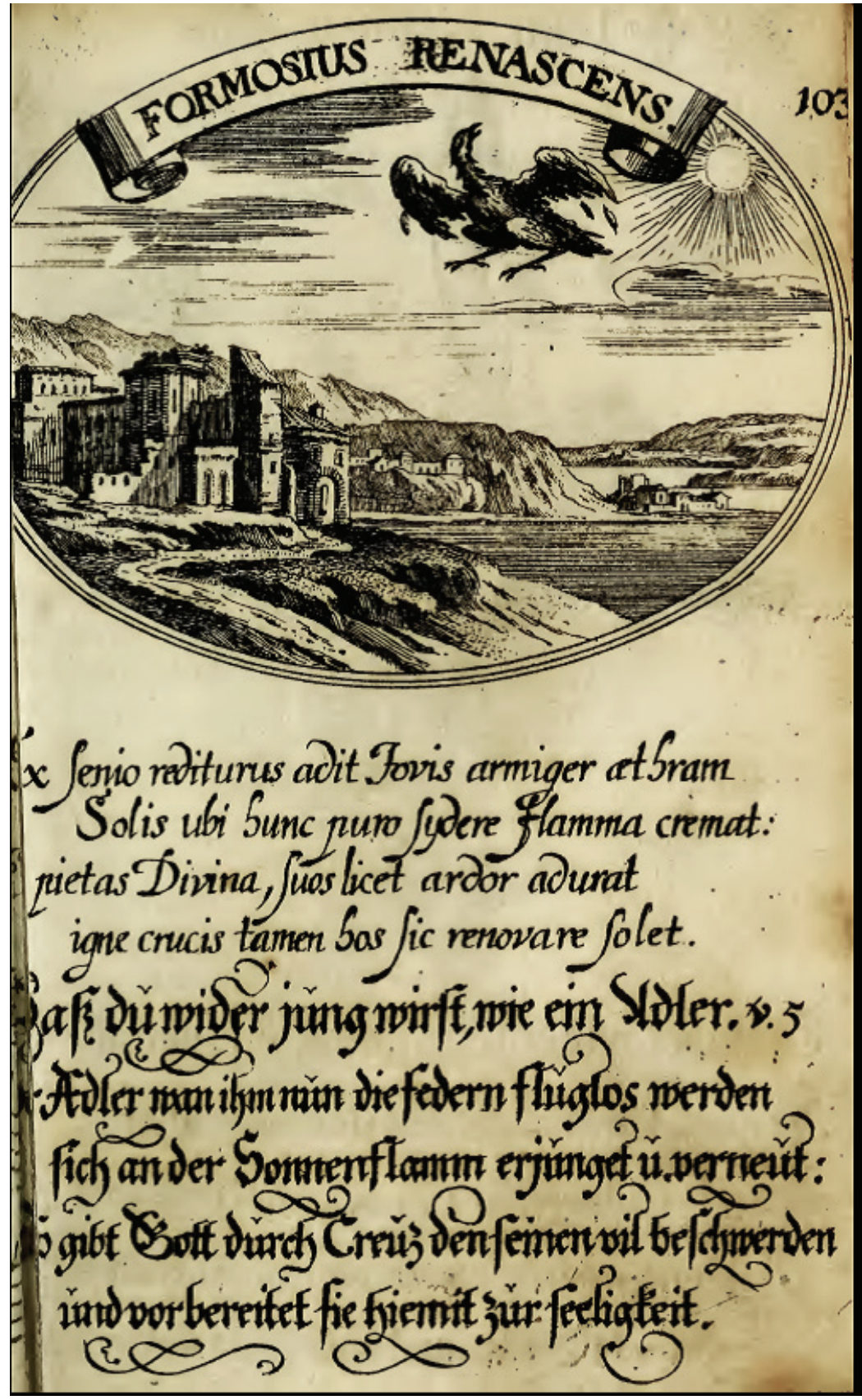

Slika 11: Cristoph Georg Eimmart, Emblem Formosus renascens, Wolfgang Helmhard von Hohberg, Lust- und Artzeney-Garten des Königlichen Propheten Davids, Regensburg 1675, fol. 103r. 
Dejstva, da je motiv orla z izpadajočimi peresi, ki leti proč od sonca, v emblematiki ustaljen ikonografski motiv, na tem mestu niti ni treba posebej dokazovati. Najdemo lahko celo prototip, po katerem se Valvasorjev emblem neposredno zgleduje. V že omenjeni Hohbergovi knjigi je na fol. 103r emblem, ki ima identično geslo kot Valvasorjev (Formosus renascens) in sličico, ki jo je Grahovar kompozicijsko skoraj v celoti povzel (slika 11). Primerjava pojasni tudi, zakaj se v emblemu Karla Jožefa Valvasorja pojavi dopolnilno besedilo: baron je očitno želel vključiti del Hohbergovega epigrama in Grahovar je vestno prepisal prva dva verza. Ikonografijo Valvasorjevega emblema dodatno osvetljujeta Hohbergova verza, ki sta v ljubljanski Spominski knjigi izpuščena: antično vsebino dopolnjujeta s krščanskim motivom preroda, ki je vizvirniku povezan $\mathrm{z}$ odrešenjem s Kristusovo smrtjo na križu. ${ }^{45}$ Kot v vseh predstavljenih emblemih se tudi tukaj heraldični orel preseli v emblemsko sličico in simbolično predstavlja samega naročnika. S posebej izpostavljeno antično ikonografijo orla kot Jupitrove svete ptice Valvasor hkrati opozarja na svoje zanimanje za kulturo klasične antike, ki so jo imeli kranjski akademiki zelo v čislih.

\section{Zaključek}

Deset emblemov z motivom orla in sonca, ki krasijo vpisne strani v Dizmovi kroniki, ima v vsebinskem pogledu veliko skupnega, vendar so $z$ ikonografskega vidika posebej zanimive prav razlike, ki so včasih očitne, spet drugič v duhu žlahtne tradicije renesančnega emblema spretno prikrite in zahtevajo dovolj pozornega bralca. Tovrstni specifični simbolni poudarki in duhovite domislice najbolje ilustrirajo inventivnost naročnikov ter pričajo o njihovem poznavanju evropske tradicije emblemskih knjig. Težnja po izvirnosti je še posebej razvidna, ko gre za oblikovanje individualne note emblemskega sporočila, s katero so želeli kranjski akademiki v Spominski knjigi pustiti oseben pečat. Ikonološka analiza izbranih emblemov ne razkriva samo njihovega vsebinskega bogastva in kompleksne strukture, različne zglede in neposredne vplive, ampak hkrati celoviteje osvetljuje dejaven pristop naročnikov. Ob tem opozarja tudi na vlogo miniaturistov, ki nikakor niso bili samo izvrševalci naročil, temveč so aktivno sodelovali pri sami ikonografski zasnovi emblemov. S tem se odpira vpogled $\mathrm{v}$ dinamiko odnosov med umetnikom in naročnikom, ki doslej v primeru ilustracij v Spominski knjigi ljubljanske plemiške družbe sv. Dizma ni bila deležna ustrezne pozornosti. Odgovori na vprašanja, ki si jih strokovna javnost do nedavnega sploh ni

45 "[...] pietas Divina suos licet ardor adurat/ igne crucis tamen has sic renovare solet." Čeprav je v motivu orlovega preroda Kristus največkrat simbolično predstavljen s soncem, je tudi interpretacija orla kot podobe Križanega uveljavljena že v srednjeveški ikonografiji. Povezava ne temelji samo na ideji odrešitve in vnebovzetja, krščanski pisci namreč silhueto orla na nebu primerjajo tudi s križem. Glej na primer: Arnold Bonnevalski, Tractatus de septem verbis Domini in cruce, 7, PL 189, 1682. 
zastavljala, sprožajo niz novih vprašanj. Kdaj in če sploh kdaj bomo našli odgovore nanje, je nemogoče napovedati. Bliskovit razvoj raziskav na področju emblematike, mednarodni raziskovalni projekti univerz in umetnostnih inštitutov, vse večja dostopnost primarnih gradiv $\mathrm{v}$ digitalizirani obliki in odkrivanje novih emblemskih knjig vsekakor obetajo, da bomo v doglednem času tudi o emblemih kranjskih akademikov vedeli še precej več kot danes.

\section{Bibliografija}

Viri

Ajlijan, Perí zóion idiótetos (De natura animalium). Dostopno $\mathrm{z}$ angleškim prevodom A. F. Scholfielda: Aelian, On the Characteristics of Animals, 3 vols. (The Loeb Classical Library), Harvard University Press, Cambridge, Mass. 1958-59.

Alciati, Andrea, Emblematum liber, Heinrich Steyner, Augsburg 1531.

Aldrovandi, Ulisse, Ornithologiae, hoc est de avibus historiae libri XII, Apud Franciscum de Franciscis Senensem, Bologna 1599.

Ambrož Milanski, Hexaemeron, Migne, PL 14, 232.

Ambrož (Psevdo), Sermo 46 de Salomone, Migne, PL 17, 718.

Apes aCaDeMICae Operosorum Labacensium, sive Institutum, leges, scopus, nomina, et symbola novae Academiae sub apum symbolo Labaci adunatae: orbi literario exhibitae cum oratione inaugurali in primo conventu publico ad proceres Aemonae dicta, Janez Jurij Mayr, Ljubljana 1701.

Aristotel, Tón perí tá zóia istoríon (Historia animalium). Dostopno z angleškim prevodom A. L. Pecka: Aristotle, History of Animals (The Loeb Classical Library), Harvard University Press, Cambridge, Mass. 1965.

Arnold Bonnevalski, Tractatus de septem verbis Domini in cruce, 7, Migne, PL 189, 1682.

Avguštin Hiponski, Enarrationes in Psalmos, Migne, PL 37.

Avguštin Hiponski, In Evangelium Joannis tractatus, Migne, PL 35, 1379-1976.

Avguštin (Psevdo), Meditationum Liber Unus, Migne, PL 40, 901-942.

Bartolomej Anglež, De proprietatibus rerum, Johannes Veldener, Köln 1471.

Bosch, Jacob, Symbolographia sive De arte symbolica sermones septem ..., Johann Caspar Bencard, Augsburg/Dilingen 1702.

Camerarius, Joachim, Symbolorum et emblematum ex animalibus quadrupedibus desumtorum centuria altera collecta, P. Kaufmann, Nürnberg 1595.

Camerarius, Joachim, Symbolorum \& emblematum ex volatilibus et insectis desumtorum centuria tertia collecta, P. Kaufmann, Nürnberg 1596.

Camerarius, Joachim, Symbolorum et emblematum ex aquatilibus et reptilibus desumptorum centuria quarta, Typis Voegelinianis, Leipzig 1604.

Dolničar, Janez Gregor, Konceptna knjiga, Semeniška knjižnica, Ljubljana, sign. Rokopis 6.

Ezop, Kritična izdaja ezopovskih basni je dostopna $\mathrm{z}$ angleškim prevodom B. E. Perryja: Babrius and Phaedrus (The Loeb Classical Library), Harvard University Press, Cambridge, Mass. 1965.

Fiziolog, Physiologos. Le bestiaire des bestiaires, Texte traduit du grec, établi et commenté par Arnaud Zucker, Éditions Jérôme Millon, Paris 2005. 
Gessner, Conrad, Historiae animalium liber III., qui est de avium natura, Christoph Froschoverus, Zürich 1555.

Giovio, Paolo, Dialogo dell'imprese militari et amorose, Antoine Barré, Rim 1555.

Gregor Veliki, Moralium Libri Sive Expositio In Librum Beati Job, II, Migne, PL 76.

Guillaume Le Clerc, Bestiaire divin, sredina 13. st., Bodleian Library, MS. Douce 132.

Hieronim, Breviarium in Psalmos, Migne, PL 26, 1097.

Hohberg, Wolfgang Helmhard von, Lust- und Artzeney-Garten des Königlichen Propheten Davids..., Christoph Fischer, Regensburg 1675.

Homer, Iliada, prev. A. Sovre, Državna založba Slovenije, Ljubljana 1982.

Horacij, Ode. Dostopno z angleškim prevodom N. Rudda: Horace, Odes and Epodes, (The Loeb Classical Library), Harvard University Press, Cambridge, Mass. 2004.

Izidor Seviljski, Ethymologiarum sive Originum liber XII. Dostopno v zbirki Latin Library: http:// www.thelatinlibrary.com/isidore/12.shtml.

Klavdijan, Panegyricus Manlio Theodoro consuli. Dostopno z angleškim prevodom M. Platnauerja: Claudian vol. I, Panegyric on Probinus and Olybrius, Against Rufinus 1 and 2. War Against Gildo, Against Eutropius 1 and 2, Fescennine Verses on the Marriage of Honorius, Epithalamium of Honorius and Maria, Panegyrics on the Third and Fourth Consulships of Honorius, Panegyrics on the Consulship of Fl. Manlius Theodorus, On Stilicho's Consulship (The Loeb Classical Library), Harvard University Press, Cambridge, Mass. 1922.

Le Brun, Laurentius, Virgilius Christianus, I. Liber Fastorum, sive Hexaemeron \& de opere sex dierum, Simeon Piget, Paris 1661.

Lukan, Mark Anej, Pharsalia (De bello civilo). Dostopno z angleškim prevodom J. D. Duffa: The Civil War Books I-X (Pharsalia), (The Loeb Classical Library), William Heinemann, London/ Harvard University Press, Cambridge, Mass. 1928.

Ovidij (Publij Ovidij Nazon), Metamorphoses. Dostopno z angleškim prevodom F. J. Millerja: Ovid, Metamorphoses, 2 vols. (Loeb Classical Library), Harvard University Press, Cambridge, Mass. 1916.

Ovidij (Publij Ovidij Nazon), Metamorfoze I.-III., prev. Barbara Šega Čeh, Modrijan, Ljubljana 2013.

Picinelli, Filippo, Mundus symbolicus: in emblematum universitate formatus, explicatus, et tam sacris quàm profanis ..., Hermann Demen, Köln 1681.

Pindar, Pitijske ode, Olimpijske ode. Dostopno z angleškim prevodom H. Racea: Pindar, Olympian Odes. Pythian Odes, vol. I (Loeb Classical Library), Harvard University Press, Cambridge, Mass. 1997.

Pindar, Istmijske ode. Dostopno z angleškim prevodom H. Racea: Pindar, Nemean Odes. Isthmian Odes. Fragments, vol. II (Loeb Classical Library), Harvard University Press, Cambridge, Mass. 1997.

Pittoni, Giovanni Battista, Imprese di diversi prencipi, duchi, signori, e d'altri personaggi et huomini letterati et illustri ..., Benetke 1562.

Plinij Starejši, Naturalis historia libri XXXVII. Dostopno z angleškim prevodom H. Rackhama: Pliny the Elder, Natural History, 10 vols. (The Loeb Classical Library), Harvard University Press, Cambridge, Mass. 1947.

Ripa, Cesare, Iconologia, Appresso Lepido Facij, Rim 1603.

Rollenhagen, Gabriel, Nucleus Emblematum selectissimorum ..., Crispijn de Passe, Köln 1611. 
Ruscelli, Girolamo, Imprese illustri ..., Francesco Rampazetto, Benetke (vol. I-III. 1572, Libro quarto 1583).

Schönleben, Janez Ludvik, Feyertäglicher Erquick-Stunden: Das ist: Ehren-vnd Lobpredigen der lieben Heiligen Gottes ... Anderer Theil, Melchior Haan, Salzburg 1670.

Sveto pismo Stare in Nove zaveze, Slovenski standardni prevod, Svetopisemska družba Slovenije, Ljubljana 1996.

Theatrum Memoriae Nobilis ac Almae Societatis Unitorum das ist Schau Bühne der Gedächtnuß der Adelichen und Gottseeligen Geselschafft der Vereinigten zu stätts wherenden Andenken eröffnet in der Uhralten Haubt Statt Laybach, Ljubljana 1688-1801, Arhiv Republike Slovenije, AS 1073, I/1.

Vergilij, Georgike, Ekloge, Eneida. Dostopno z angleškim prevodom H. R. Fairclougha: Virgil, Eclogues. Georgics. Aeneid. Books I-VI, (The Loeb Classical Library), William Heinemann, London/ Harvard University Press, Cambridge, Mass. 1916.

Vergilij, Eneida. Dostopno z angleškim prevodom H. R. Fairclougha: Virgil, Aeneid, Books VII-XII, Appendix Vergiliana (The Loeb Classical Library), William Heinemann, London/ Harvard University Press, Cambridge, Mass. 1918.

Zani, Valerio, Memorie, Imprese, e Ritratti de’ Signori Accademici Gelati de Bologna ..., Manolesi, Bologna 1672.

\section{Strokovna literatura}

Baraga, France, Dolničarjeva Konceptna knjiga ljubljanske plemiške družbe sv. Dizma, Uvodna pojasnila, v: Spominska knjiga ljubljanske plemiške družbe sv. Dizma 1688-1801, I (ur. Gostiša, L.), Fundacija J. V. Valvasorja, Ljubljana 2001, str. 235-236.

Cevc, Emilijan, Iluminirani kodeks ljubljanske plemiške družbe sv. Dizma v: Spominska knjiga ljubljanske plemiške družbe sv. Dizma, 1688-1801, II (ur. Gostiša, L.), Fundacija J. V. Valvasorja, Ljubljana, 2001, str. 67-113.

Dolinar, France Martin, Od Dizmove bratovščine do Akademije delovnih v Ljubljani, v: Academia Operosorum, zbornik prispevkov s kolokvija ob 300-letnici ustanovitve, (ur. Gantar, K.), SAZU, Ljubljana 1994, str. 35-46.

Germ, Martin, Iconography of Emblematic Animals in the Album of the Ljubljana Noble Society of St Dismas: Readings and Misreadings, IKON Journal of Iconographic Studies, 2 (2009), str. 305-312.

Germ, Tine, Spominska knjiga ljubljanske plemiške družbe sv. Dizma: zgodovinski kontekst nastanka in njeni idejni vzori. Arhivi, 34/1 (2011), str. 33-40.

Germ, Tine, Smrt kraljuje povsod in bela Smrt triumfira: Valvasorjevo Prizorišče človeške smrti v evropskem kontekstu, Znanstvena založba FF, Ljubljana 2015.

Germ, Martin, The emblems of the Album of the Ljubljana Noble Society of St Dismas: Context, Sources, Originality, Ars \& humanitas, 11/1 (2017), str. 149-170.

Golob, Nataša, Spominska knjiga ljubljanske plemiške družbe sv. Dizma. Kodikološke ugotovitve, v: Spominska knjiga ljubljanske plemiške družbe sv. Dizma 1688-1801, II (ur. Gostiša, L.), Fundacija J. V. Valvasorja, Ljubljana 2001, str. 41-47.

Gradel, Ittai, Emperor Worship and Roman Religion, OUP, Oxford 2002.

Henkel, Arthur; Schöne, Albrecht, Emblemata. Handbuch zur Sinnbildkunst des XVI. und XVII. Jahrhunderts, J. B. Metzler, Stuttgart 1967. 
Kastelic, Jože, Emblemi v ikonografskem ogledalu. Katalog, v: Spominska knjiga ljubljanske plemiške družbe sv. Dizma 1688-1801, II (ur. Gostiša, L.), Fundacija J. V. Valvasorja, Ljubljana 2001, str. 119-261.

Lavrič, Ana, Societas Unitorum - Akademija Združenih, v: J. G. Dolničar, Zgodovina ljubljanske stolne cerkve, (ur. Lavrič, A.), Založba ZRC, Ljubljana 2003, str. 27-30.

Lisac, Ljubomir Andrej; Reisp, Branko, s. v.: Trost, Andrej, Slovenski biografski leksikon, IV, Ljubljana, 1960, str. 186-187; http://www.slovenska-biografija.si/oseba/sbi724835/.

Miklavčič, Maks, s. v.: Schönleben, Janez Ludvik, Slovenski biografski leksikon, X, Ljubljana 1967; http://www.slovenska-biografija.si/oseba/sbi548709/.

Panofsky Ervin, Hercules am Scheidewege und andere antike Bildstoffe in der neuen Kunst (Studien der Bibliothek Warburg, Band 18), Teubner Verlag, Berlin 1930.

Schnabel, Werner Wilhelm, Das Stammbuch. Konstitution und Geschichte einer textsortenbezogenen Sammelform bis ins erste Drittel des 18. Jahrhunderts, Niemeyer, Tübingen 2003.

Smolik, Marijan, Pregled članstva ljubljanske plemiške družbe sv. Dizma, v: Spominska knjiga ljubljanske plemiške družbe sv. Dizma 1688-1801, II (ur. Gostiša, L.), Fundacija J. V. Valvasorja, Ljubljana 2001, str. 263-275.

Vignau-Wilberg, Thea, Archetypa studiaque patris Georgii Hoefnagelii, 1592: Natur, Dichtung und Wissenschaft in der Kunst um 1600, Staatliche Graphische Sammlung, München 2005.

Vidmar, Luka, Ljubljana kot novi Rim. Akademija Operozov in baročna Italija, Založba ZRC, Ljubljana 2013.

Vrhunc, Polonca, Simon Tadej Volbenk Grahovar (1710-1774), Zbornik za umetnostno zgodovino, n. v. 8 (1970), str. 107-132.

Tine Germ

\section{Simbolika orla in sonca v emblemih Spominske knjige ljubljanske plemiške družbe sv. Dizma}

Ključne besede: Spominska knjiga ljubljanske plemiške družbe sv. Dizma, renesančna in baročna emblematika, simbolika orla in sonca, knjižna iluminacija, Janez Gregor Dolničar, Andrej Trost, Simon Tadej Volbenk Grahovar

Avtor v svoji študiji analizira ročno slikane embleme z motivom orla in sonca v Spominski knjigi ljubljanske plemiške družbe sv. Dizma (skrajšano: Dizmova kronika), hranjene v Arhivu Republike Slovenije (ref. AS 1073, I/1), ki so z ikonografskega vidika skoraj povsem neraziskani. Kratkemu uvodu, v katerem je predstavljena Dizmova kronika kot izvirna oblika emblemske spominske knjige, ki je nastajala v Ljubljani med letoma 1689 in 1801, sledi ikonološka analiza desetih emblemov z motivom orla in sonca (fols. 119r, 161r, 229r, 234r, 238r, 264r, 287r, 294r, 306r, 369r) v kontekstu evropske emblematike. Avtor najprej opozori na ikonografska izhodišča motiva ter opredeli osnovni vsebinski okvir, ki je skupen vsem emblemom z motivom orla in sonca v Dizmovi kroniki. Gre za večinoma kristološko ikonografijo, ki izhaja iz biblijske eksegeze, Fiziologa in srednjeveških bestiarijev, največji razcvet pa doživi prav na področju emblematike 
v zgodnjem novem veku. Skupno vsebinsko jedro oblikujejo motivi preroda, odrešenja in večnega življenja ter simbolične predstave o sledenju Kristusovemu nauku in odličnosti duha, ki se dviga v nebeške višave. Analiza pokaže, da imajo ključno vlogo motivi, ki izvirajo iz antike, a so v krščanstvu dobili nove, precej bolj kompleksne vsebine: orel, ki nemoteno zre v sonce, orel, ki leti proti soncu, preizkušnja mladih orličev z gledanjem v sonce ter orel, ki uči mladiče leteti.

Raziskava se osredotoča na ikonografsko specifiko vsakega posameznega emblema, v kateri sta razvidna inventivnost naročnikov in njihovo poznavanje evropske tradicije emblemskih knjig. Analiza izbranih emblemov ne razkriva samo njihovega vsebinskega bogastva in kompleksne strukture, različne zglede in neposredne vplive, ampak hkrati celoviteje osvetljuje dejaven pristop naročnikov v procesu njihovega nastajanja, ki doslej v primeru ilustracij v ljubljanski Spominski knjigi ljubljanske plemiške družbe sv. Dizma ni bil deležen ustrezne pozornosti. Ob tem avtor opozarja tudi na vlogo vodilnih miniaturistov Andreja Trosta in Simona Tadeja Volbenka Grahovarja, ki nista bila zgolj iluminatorja, temveč sta aktivno sodelovala pri sami ikonografski zasnovi emblemov, s čimer odpira nov vpogled $\mathrm{v}$ dinamiko odnosov med umetnikom in naročnikom.

\section{Tine Germ}

\section{The Eagle and the Sun Symbolism in the Emblems of the Album of the Liubljana Noble Society of St Dismas}

Keywords: The Album of the Ljubljana Noble Society of St Dismas, Renaissance and Baroque emblems, the eagle and the sun symbolism, manuscript illumination, Janez Gregor Dolničar, Andrej Trost, Simon Tadej Volbenk Grahovar

The paper provides an analysis of the hand-painted emblems with the motifs of the eagle and sun in the Album of the Ljubljana Noble Society of St Dismas (the Archive of the Republic of Slovenia, ref. AS 1073, I/1). These have so far barely received any iconographic interpretation, nor have there been any serious attempts to identify the potential sources or models. A short introduction points to the original form of the Ljubljana Album as a memorial book with individual emblems created for the members of the Society of St Dismas between 1689 and 1801. The focus of the article is on the iconological analysis of ten emblems with the motifs of the eagle and the sun (the Ljubljana Album, fols. 119r, 161r, 229r, 234r, 238r, 264r, 287r, 294r, 306r, 369r) in the context of European emblematics. The author draws attention to the iconographic specifics of each individual emblem, as well as to the basic symbolism of the eagle and sun which is common to all of them.

While the common iconography of the motif in the selected emblems in the Ljubljana Album regularly relates to the Christological contexts of the eagle and the sun symbolism as developed in the biblical exegesis, Physiologus, the medieval bestiaries and various theological writings, the individual allegorical message depends on the complex interaction of visual and textual components of each emblem. The traditional Christological topics of renewal through strong faith and repeated purification of body and mind, the ascending of the Spirit into higher 
realms, the salvation of the soul in Christ and the eternal life in Heaven, are often completed with themes which originate in Classical mythology and ancient animal lore. Some motifs that combine both Christian and Classical symbolism of the eagle and the sun appear to have been particularly appreciated among the members of St Dismas Society: the eagle looking unblinking into the sun, the eagle flying towards the sun, the trial of eaglets gazing at the sun, and the eagle teaching eaglets to fly. The iconographic particularities of each emblem show the erudition of the patrons as well as their knowledge of European books of emblems. The analysis of the assorted emblems goes beyond mere presentation of their rich content and complex structure, their various models and influences; it also brings an in-depth look at the patrons' active involvement in the creative process which, in the case of the Album of the Ljubljana Noble Society of St Dismas, has not yet been dealt with properly. It furthermore draws attention to the role played by the two leading miniaturists Andrej Trost and Simon Tadej Volbenk Grahovar, who occasionally advised the patrons on both visual and iconographic components of the emblems, thus acting not only as illuminators but also as creators of the emblems.

\section{O avtorju}

Tine Germ je redni profesor na Oddelku za umetnostno zgodovino Filozofske fakultete Univerze v Ljubljani, strokovnjak za ikonografijo in ikonologijo poznega srednjega in zgodnjega novega veka. Njegove raziskave se osredotočajo na humanistične teme v renesančni umetnosti, na renesančno in baročno emblematiko ter ikonografijo živali v umetnosti zgodnjega novega veka.

\section{About the author}

Tine Germ is a Professor at the Department of Art History, Faculty of Arts, University of Ljubljana, an expert in iconography and iconology of Late Mediaeval and Early Modern Art. His research work focuses on humanistic themes in Renaissance Art, Renaissance and Baroque emblems, and animal symbolism in Early Modern Art. 